\title{
Assessment of Beshagard Mountain Tectonic Activity (South of Jazmurian Depration) Application IRAT Index
}

\section{Ali Khoddami Atashan1, Mohsen Pourkermani², Amir Shafii Bafti³, Manouchehr Ghorashi, Soheila Bouzari ${ }^{5}$}

${ }^{1}$ Department of Geology, Islamic Azad University, North Branch, Tehran, Iran

${ }^{2}$ Department of Geology, Faculty Members of Islamic Azad University, North Branch, Tehran, Iran

${ }^{3}$ Department of Geology, Faculty Members of Islamic Azad University, Zarand, Iran

${ }^{4}$ Research Institute for Earth Sciences-Geological Survey of Iran, Tehran, Iran

${ }^{5}$ Department of Geology, Faculty Members of Islamic Azad University, North Branch, Tehran, Iran

Email:khodamia.t@gmail.com

How to cite this paper: Atashan, A.K., Pourkermani, M.P., Bafti, A.S. Ghorashi, M. and Bouzari, S. (2017) Assessment of Beshagard Mountain Tectonic Activity (South of Jazmurian Depration) Application IRAT Index. Open Journal of Geology, 7, 295-319.

https://doi.org/10.4236/ojg.2017.73021

Received: February 2, 2017

Accepted: March 21, 2017

Published: March 24, 2017

Copyright $\odot 2017$ by authors and Scientific Research Publishing Inc. This work is licensed under the Creative Commons Attribution International License (CC BY 4.0).

http://creativecommons.org/licenses/by/4.0/

\begin{abstract}
Morphometry status of tectonic active areas around the Beshagard mountain is as a result of the interaction of neotectonic movements, erosion and subsidence processes. Bashagard mountain contains two attached mountains (GhaleTohi imountain and Bashagard mountain) with an altitude of 2000 meters at the south of the Jazmurian subsidence surrounded by Quaternary and Neogene. The boundary between the north Makran and Jazmurian subsidence is a fault that located between Band-e-Ziarat unit and western alluvial fan and units of Ganj, Mokhtarabad and Rameshk in the south. Tectonic activity has a significant impact on their morphometry status and drainage basin system. We studied geomorphological patterns of drainage and mountain fronts features for clear changes and high style of mountain. In this study, we studied seven geomorphological indicators for each basin including $V f, B s$, $S m f, S I, A f, R A, H i$ between west and south mountain front of Jazmurian. Morphometric indexes were divided in three categories. The average of seven indicators is an index of relative tectonic activity (IRAT). The level of tectonic activity of each IRAT category was determined. Finally, tectonic activity was evaluated for each drainage basin. Results show good similarity between IRAT category and ratio of tectonic activity of the number of drainage basins. The streams profile shows the uplift movement in the western part of subsidence Jazmurian. Thus, the achievements obtained from the analysis of topographic indices, the region's river system and geomorphological evidence show the movements of uplift and movement of right-lateral strike-slip of Jiroft fault in the west and reverse faulting of Kranj and Jazmurian faults at east of subsidence Jazmurian that all indicates the diagonal tectonic movements.
\end{abstract}




\section{Keywords}

Morphometry, Beshagard Mountain, Jiroft Fault. Active Tectonic , IRAT

Index

\section{Introduction}

Active tectonics is one of the fastest growing disciplines among the earth sciences considering the recent developments of new geochronological tools and mapping that assist to obtain uplift rate, shear rate, erosion rate, fault slip rate and... in variable time scale $(10,001,000,000$ years) [1] [2] [3].

Tectonic geomorphology is a relatively new field in active tectonic that provides a valuable tool for assessing the tectonic activity of structures with low to medium deformation rate, especially when there is a lack of Quaternary age [4]. The results of regional studies in tectonic active area are important for natural hazards assessment, planning and management of land use in densely populated [2] [3]. That in addition to its social and economic benefits, active tectonic study is a multidisciplinary approach that structural geology, geomorphology, stratigraphy, archeology, geology, earthquake and mapping are directed toward it with data integration [3].

With obtaining simpler data from DEM with high precision and remote sensing, a growing number of achievements in response to faults morphology and active folds that have been created over the past three decades [3] [5] guide us to understand active tectonics of the region and remote areas covered by Quaternary deposits and clear signs [6].

These studies to understand the movement and the mechanical development of regional active tectonic are useful. The active tectonic is the main cause of uplift of mountains stone blocks, and the presence of their new topography is because of difference between the tectonic and attrition processes [2] [3].

Topography, drainage pattern analysis and morphometric indices can be used for evaluation of recent tectonic activity [1] [3] [6] [7]. Drainage pattern in active tectonic areas is sensitive to active processes such as folds and faults, channels incision, asymmetry of basin, diversion of canals and other effects can be considered as the results of these processes [3]. Numerical and surface data of morphology or new sediments are used to obtain the rate of tectonics (faults, folds, etc.) and morphological processes (incision of channels etc.) [3] [7].

The analysis of the catchment is a powerful tool for identification of recent tectonic activities and uplift, for example, river channels are very sensitive to changes in the parameters, which control their shape and slope [4].

The morphometry index assesses the situation and prevalence of tectonic activities. El Hamdouni et al. (2008) divided six indices to 4 categories using calculation of IRAT along the southwestern of Sri Nevada in southern of Spain and tectonic activity. IRAT classified. This study showed that the proportion of high potential of continues tectonic activity associated with IRAT values. Mahmood 
and Gloguen (2012) calculated seven morphometry indices using calculation of values of IRAT using GIS in the Hindu Kush, Karakoram and Himalayas. The values of IRAT index are in accordance with the rate of uplift, geomorphological and geological characteristics. Gao et al. (2013) used the morphometry indices such as hypsometric curve and longitudinal gradient of river to find the tectonic activity and assess recent uplift the northeast margin of the Tibetan plateau. Alipoor et al. (2011) evaluated morphometry indices around the dam of Rudbar, Lorestan, in high Zagros belt (the southwestern of Iran). In this way, strong tectonic thus can be developed the morphologies of the remaining streams. In this study, we studied a large area of Bashagard mountain in the south of Jazmurian subsidence (northern Makran, south and south-eastern of Iran) using morphometry indices and pattern morphometry analysis of the catchment. The technique involves the extraction of drainage basins of DEM, calculation of morphometry index, estimating IRAT, classification of IRAT levels and determination of relationship between the IRAT level and distribution of tectonic activity in the drainage basin.

\section{Geology and Tectonic}

Bashagard Mountains are located in northern Makran (south of Jazmurian subsidence). Northern Makran is the most northern part of Makran incremental prism (the largest incremental prism in the world), which is located in southeastern of Iran and southern of Pakistan with the length of $850 \mathrm{~km}$ from the Strait of Hormuz in the West to near Karachi in the East. Prism width is from 300 to $350 \mathrm{~km}$ from deformation in front of the coast to Jazmurian subsidence in Iran and Meshkel in Pakistan (Figure 1). The subduction probably began during the Paleocene that led to start accretion during the Eocene and new accretionary prism from the end of Miocene [11] [12]. The active convergence rate between the Arabian plate and Makran coast that measured in Muscat of Oman and Chabahar coast of Iran, is $1.9 \mathrm{~cm}$ per year. Today the convergence rate between the Makran coast (Chabahar GPS) and Eurasian shield is $8 \mathrm{~mm}$ per year (Figure 2) [12] [13].

Northern Makran includes Bashagard thrust sheet and imbricate zone includes Bande Ziarat complex, Ganj, Rameshk, Mokhtarabad and Kamsafid of Cretaceous and Eocene sediments determined with basic to high basic rocks (Figure 1(A) and Figure 1(B)). The upper cretaceous rocks have been resulted from the southern parts and have been covered by olistostrome. Moreover, it includes weak folds with long wavelength with low amplitude and the general trend of eastern-western [15] [16]. Usually, thrust faults have the slope direction towards north-northeast. Imbricate zone, which is mainly located at the eastern edge of Jazmurian dredged, is highly faulted and includes left-lateral strike-slip and is in connection with conjugate faults right-lateral strike-slip with northwest-southeast direction and reverse and normal faults directing northwestsoutheast to north-south.

The geological study area has a very complex structure that this complexity is 
in terms of its instability, lithology compounds of different rocks and tectonic situation.

Connection between Jazmurian in north of Makran accretionary prism to south is generally fault [15] [16]. The southeast border of Jazmurian is continued towards east-west that has the maximum number of normal and reverse faults such as Karang that separates southern border of the Jazmurian subsidence from the mountain with reverse function and is continued from Esfand towards the east with approximate length of $60 \mathrm{~km}$ with directions of N45W, W-E"N-S and N70E (Figure 3). The Jazmurian fault is located following the Karang fault with east-west direction and the thrust type and approximate length of $42 \mathrm{~km}$ (Figure 3 ), as the southern border Jazmurian is almost eastern-western of and is continued from Beijing to southeast with the Ganj fault with almost length of $49 \mathrm{Km}$ with the length of N65W. The same time northern border of that load unit is located with Cretaceous and its Rameshk unit southern boundary is with Eocene. The load unit trusted on Rameshk unit. The function of the mentioned fault is the thrust type (Figure 3).
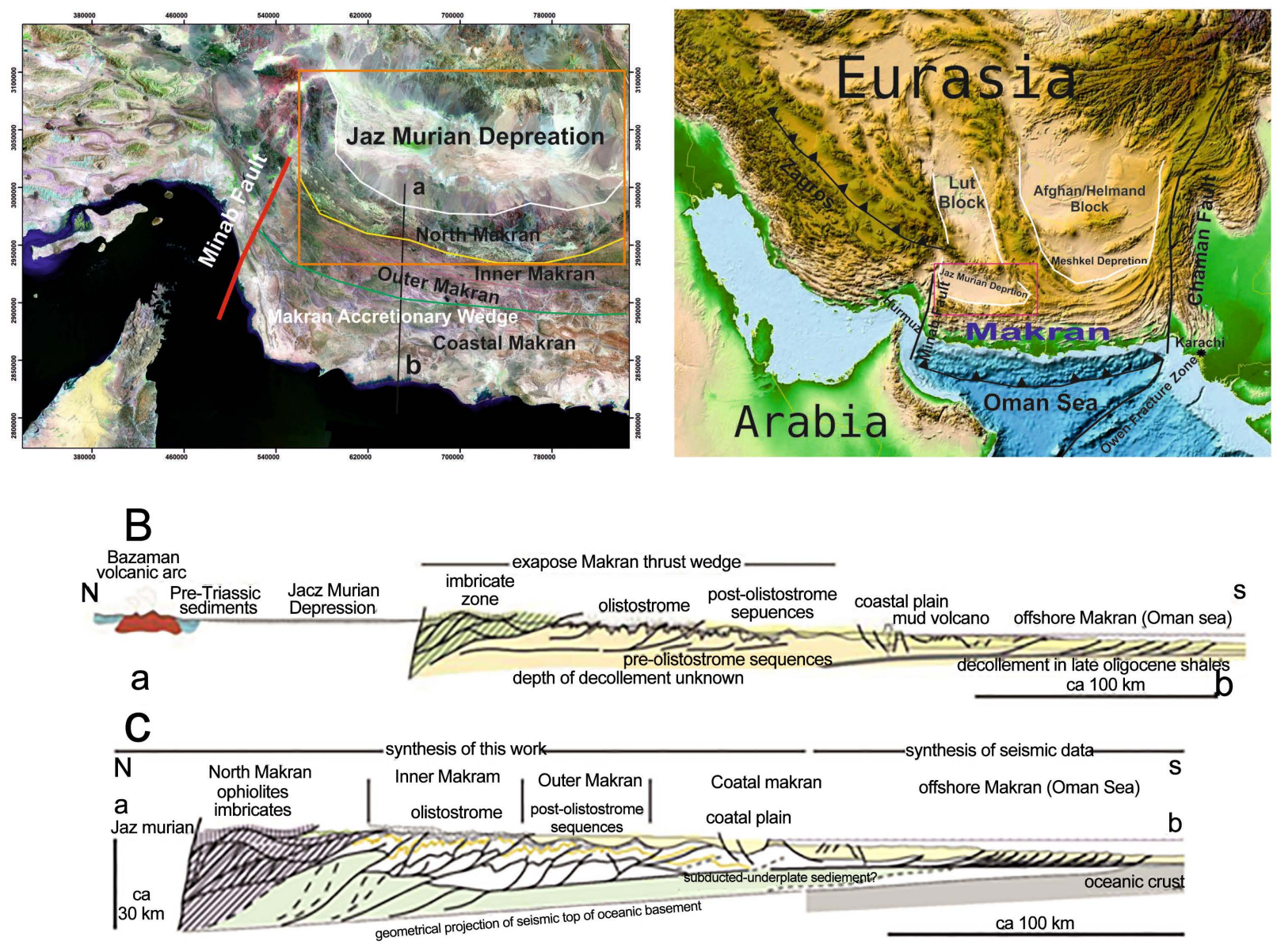

Figure 1. The tectonic situation of Makran subduction on the satellite images shows collision and convergence of EurasianArabian plate. (A) The main structural situation of states of Makran on the image of Landsat satellite; (B) The made cross section of Makran subduction system [12] [14]. (C) The made cross section of main states of Makran [16]. 


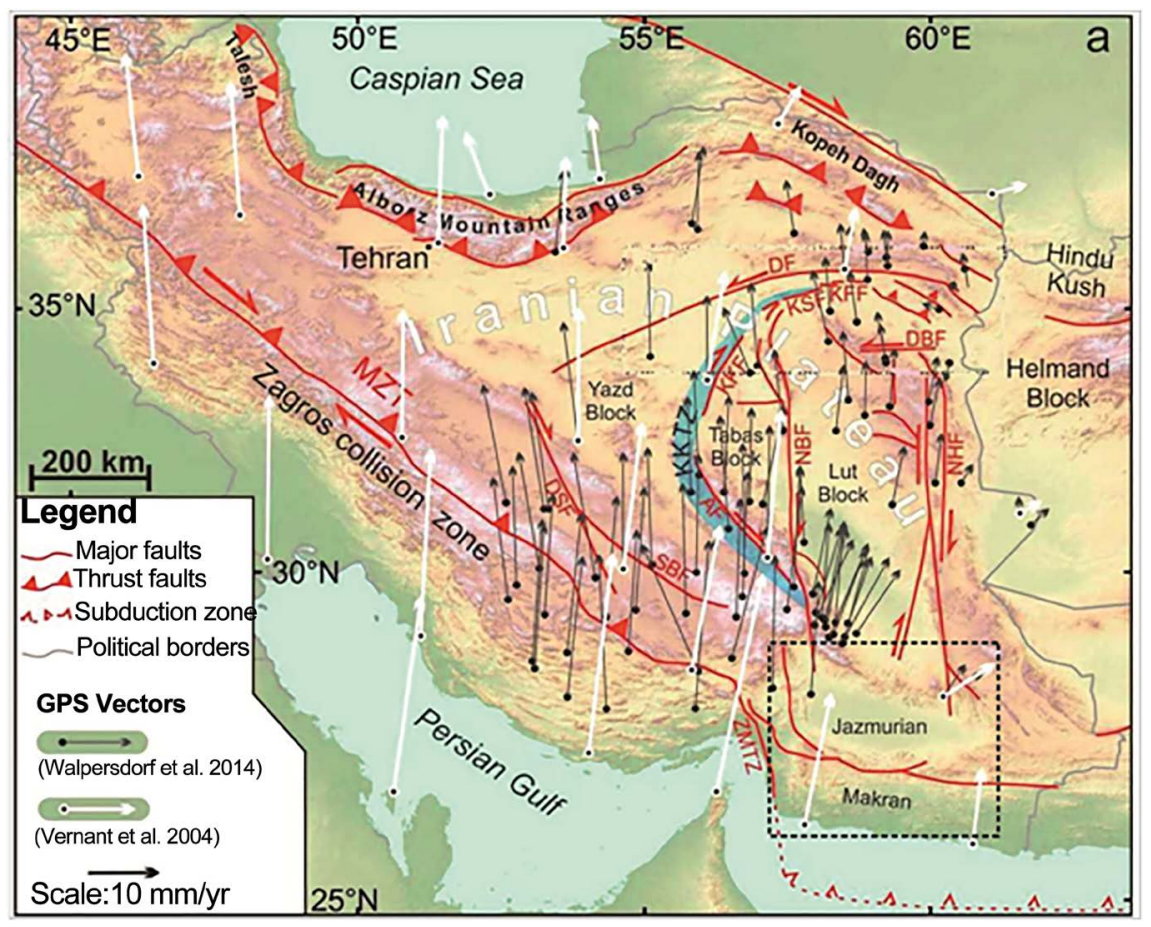

Figure 2. Simplified geological map of Iran (simplified after [8], velocity vectors of GPS of Iran comparing to Eurasia shields have been shown with different colors based on [12] [13]).

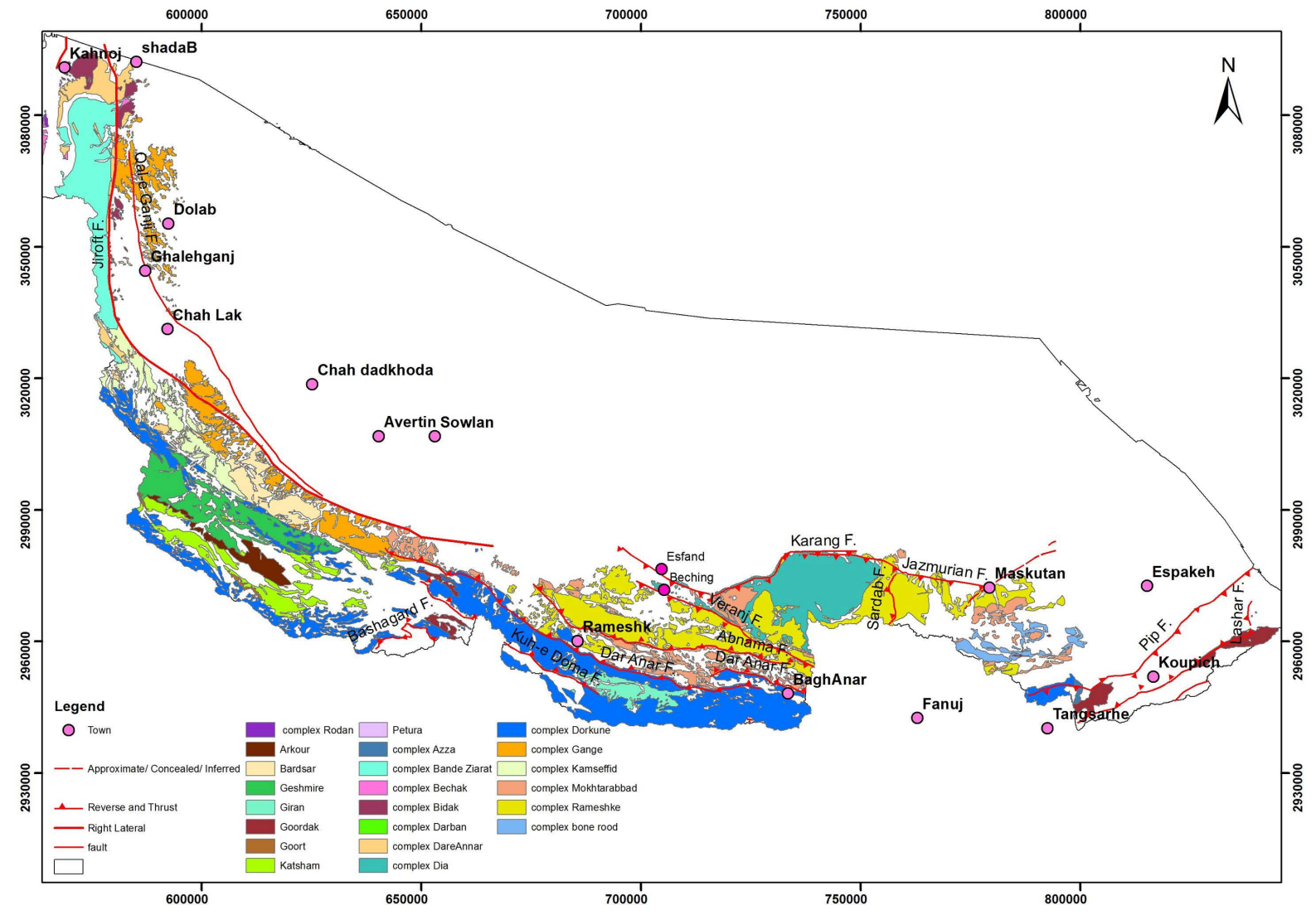

Figure 3. Map of structural-sedimentary units of Bashagard mountain [17]. 
West border of Bashagard mountain forms the Jiroft fault with a length of about $130 \mathrm{~km}$ with northern-southern and northwestern-southeastern directions. This fault system caused a separation in alluvial deposits in past 22 and 42 thousand years with the values of 49 and 132 meters, respectively. The average movement rate of this fault has been calculated about $2.7 \pm 0.7 \mathrm{~mm}$ per year (Figure 3 and Figure 4).

The mentioned fault with approximate direction of northern-southern is finished with direction of northwest-southeast at the end with the right-lateral strike-slip function. One of other structures of the west is Ghale Ganj fault with a length of almost $90 \mathrm{~km}$ from Shadab in north after passing through the town of Ghale Ganj to Dadkhoda well in the south with the northern-southern trend to N15W parallel to the Jiroft fault that separated Ganj unit from the Quaternary sediments (Figure 3).

\section{Indices of Morphometry}

We obtained five morphometric indices of mountain front sinuosity $(S m f)$, index of basin shape, valley floor width to height ( $V f)$, basin asymmetry $(A f)$, basin shape $(B s)$ and watersheds of Bashagard mountain with respect to the resistance of rock area (Figure 5) and erosion map of area (Figure 6). Then, they were divided into three categories based on division of digital morphometry [8] [19] [20].
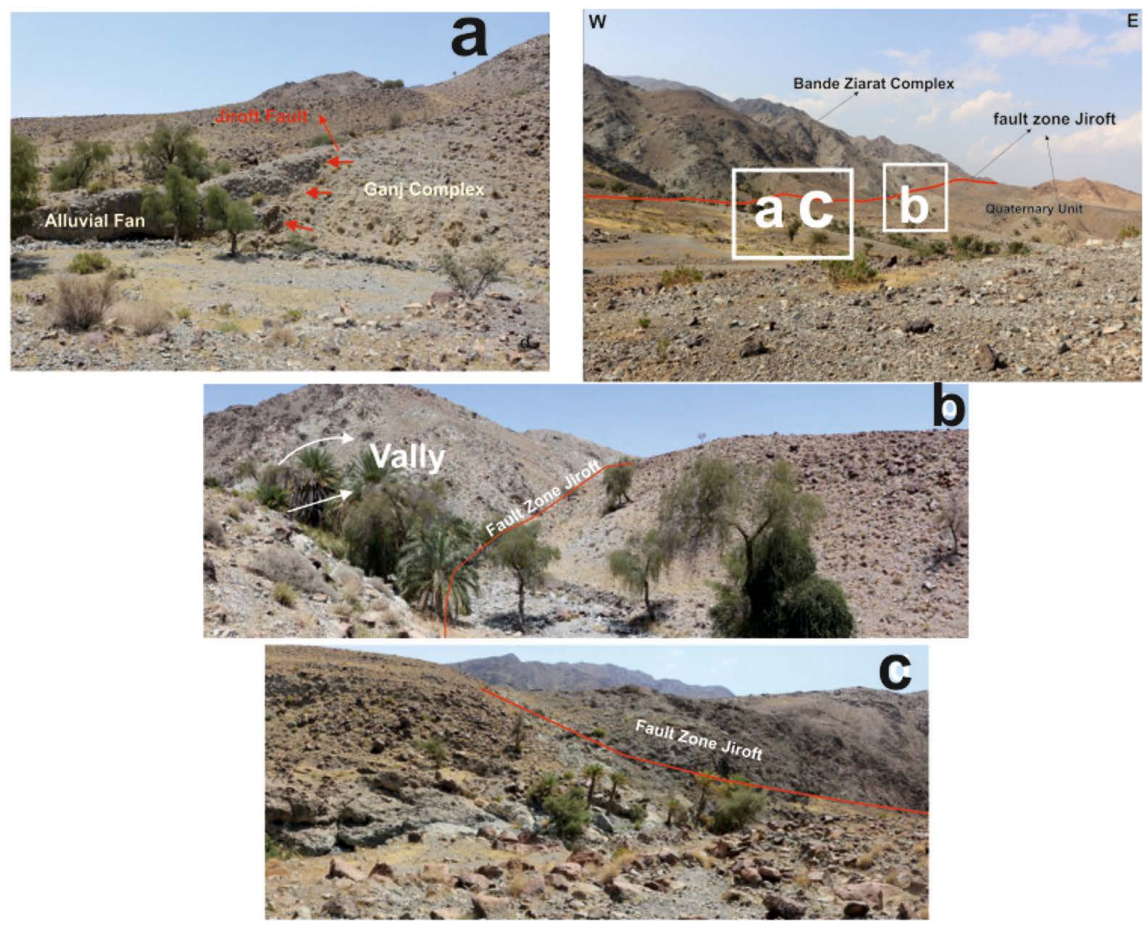

Figure 4. (a) (c) A view of Jiroft fault, which caused the separation of Bande Ziarat from the quaternary sediments; (b) The Jiroft fault zone and narrow and steep valleys created by the Negah fault at the north. 


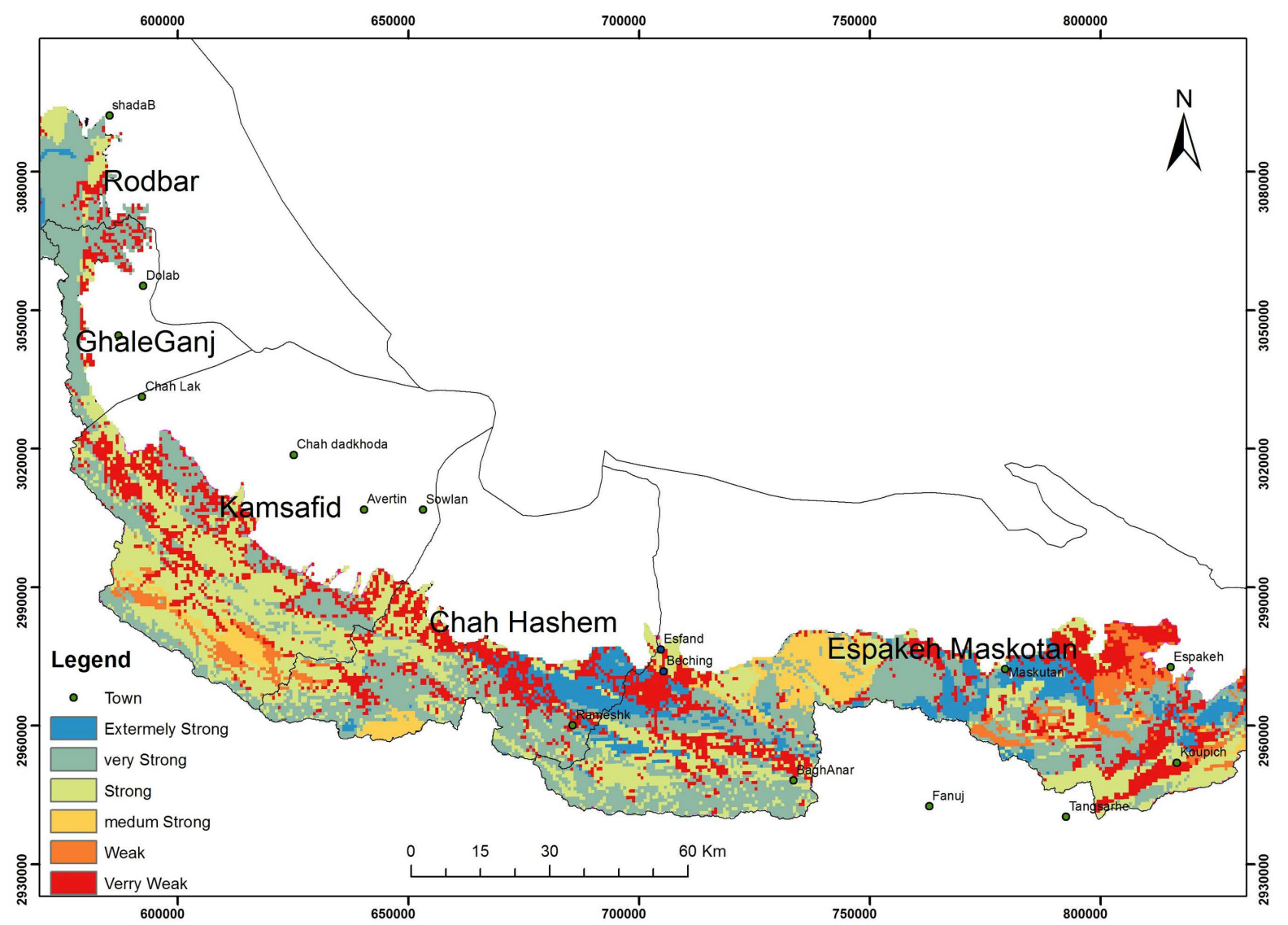

Figure 5. Map of stone resistance of Bashagard mountain based on engineering division [18].

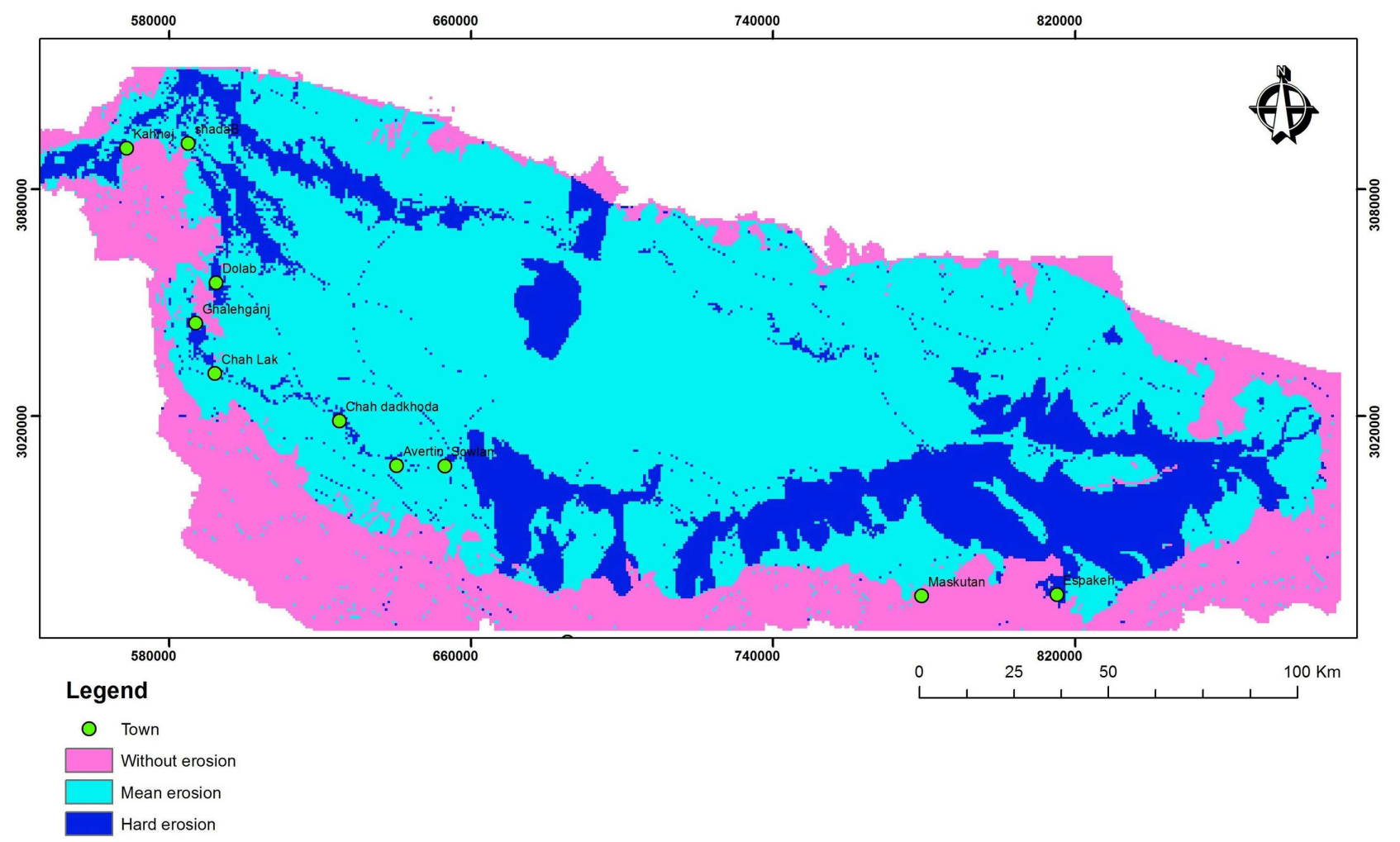

Figure 6. Map of Bashagard mountain erosion in south and north of Jazmurian subsidence. 


\subsection{Index Mountain Front (Smf)}

Mountain front maze index is calculated by the following equation [21].

$$
S m f=L m f / L s
$$

where, $\operatorname{Lmf}$ is the length of mountain front during connection of mountain with alluvium, $L s$ is the length of the straight line of mountain front. This index has been also used to assess the relative of tectonic activity [1] [19] [22].

We calculated the mountain maze index by measuring the amount of Lmf, Ls in the east, south and west of Jazmurian subsidence in the north of Bashagard mountain (Figure 7) and the results have been given in Table 1. The values of this index is changed in the range of $0.89-2.7$ (Table 2 and Figure 18). The average of mountain maze index is 1.49 for west front and 1.42 foe east front. These values show that these areas are active. This index for west mountain front is 1.61 that shows the lower activity of this region. In addition, we combined this index with the maps of rock resistance (Figure 5) and erosion (Figure 6) and finally, we created the map of tectonic activity of the region (Figure 8).

Among the distribution of $\operatorname{Smf}$ categories in the studied range in Figure 8, categories 1 and 2 have the maximum spread that convergence is caused by the tectonic collision activities. Category 2 in the south and east mountain has a relatively lower tectonic activity. Category 3 has the lowest distribution and dale hill areas.

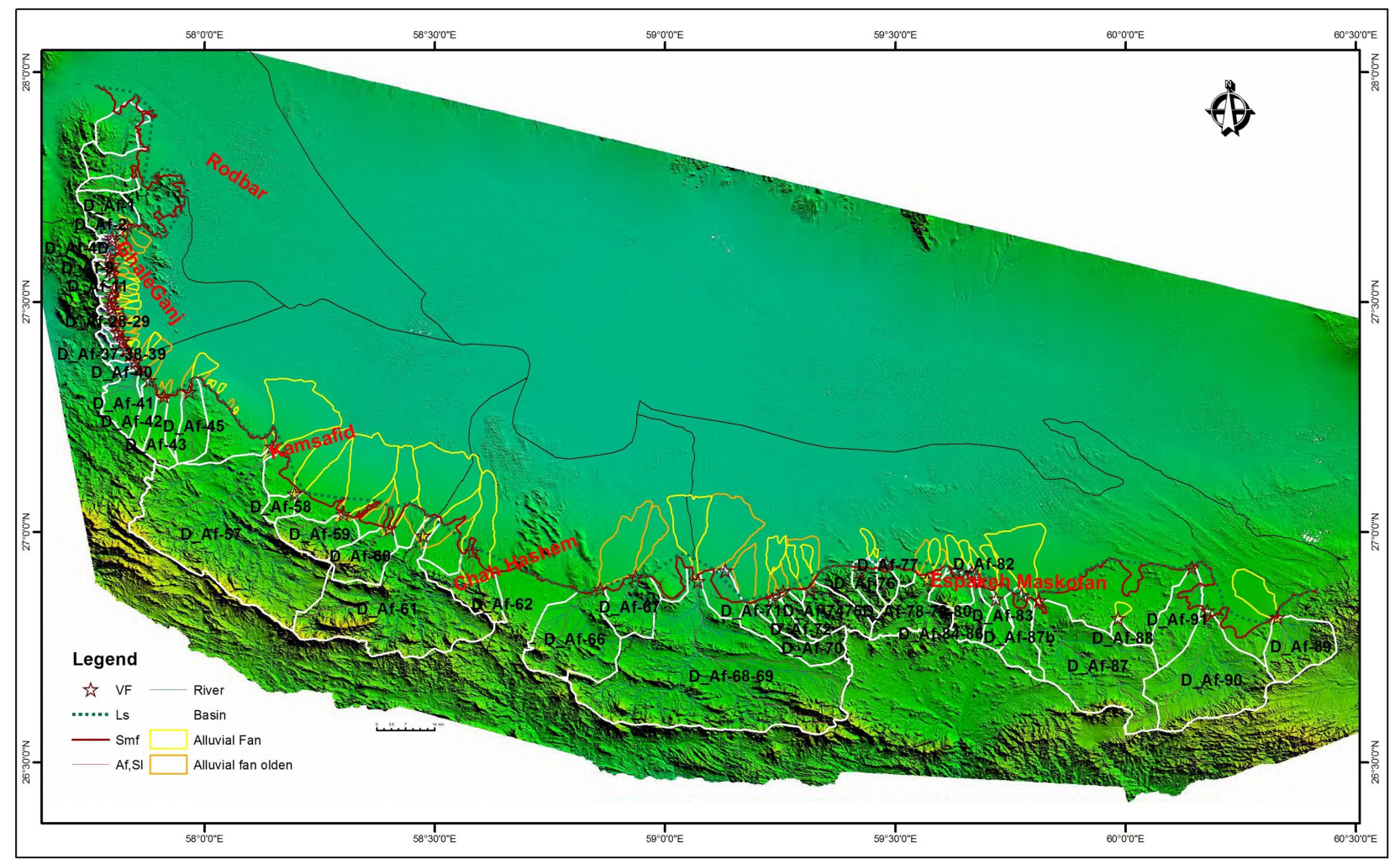

Figure 7. Map of the Bashagard mountain watersheds on the SRTM image with an accuracy of ten meters. 
Table 1. Classification of morphometry index values based on division of [8] [19] [20].

\begin{tabular}{cccc}
\hline Morphology index & Category1 & Category2 & Category3 \\
\hline$R A$ & $R A<1000$ & $500<R A<1000$ & $R A>500$ \\
$V f$ & $V f>0.3$ & $1>V f>0.3$ & $V f>1$ \\
$S m f$ & $S m f<1.1$ & $1.1<S m f<1.5$ & $S m f>1.5$ \\
$A f$ & $A f<35$ or $A f>63$ & $57<A f<65$ or $35<A f<43$ & $43<A f<57$ \\
$S I$ & $S I>400$ & $200<S I<400$ & $S I<200$ \\
$B s$ & $B s<1.2$ & $1.2<B s<0.8$ & $B s<0.4$ \\
$H i$ & $H i>0.5$ & $0.4<H i<0.5$ & $H i<0.4$ \\
\hline
\end{tabular}

Table 2. The features of Bashagard mountain watersheds.

\begin{tabular}{|c|c|c|c|c|c|}
\hline Location & Area $\left(\mathrm{Km}^{2}\right)$ & Name & Location & Area $\left(\mathrm{Km}^{2}\right)$ & Name \\
\hline \multirow{5}{*}{ Kamsafid } & 1066.96 & D_Af-57 & \multirow{26}{*}{ GhaleGanj } & 75.51 & D_Af-1 \\
\hline & 1066.96 & D_Af-58 & & 25.54 & D_Af-2 \\
\hline & 375.78 & D_Af-59 & & 2.57 & D_Af-3 \\
\hline & 375.78 & D_Af-60 & & 5.33 & D_Af-4 \\
\hline & 936.69 & D_Af-61 & & 9.72 & D_Af-4D \\
\hline \multirow{3}{*}{ ChahHashem } & 936.69 & D_Af-62 & & 4.61 & D_Af-5 \\
\hline & 322.16 & D_Af-66 & & 4.3 & D_Af-8 \\
\hline & 157.59 & D_Af-67 & & 7.2 & D_Af-9 \\
\hline \multirow{18}{*}{$\begin{array}{l}\text { Espakeh } \\
\text { Maskotan }\end{array}$} & 1245.91 & D_Af-68-69 & & 5.5 & D_Af-11 \\
\hline & 228.09 & D_Af-70 & & 3.2 & D_Af-13 \\
\hline & 228.09 & D_Af-71 & & 4.7 & D_Af-141619 \\
\hline & 228.09 & D_Af-72 & & 3.97 & D_Af-20 \\
\hline & 262.62 & D_Af-7475 & & 1.54 & D_Af-21 \\
\hline & 262.62 & D_Af-76 & & 1.17 & D_Af-23 \\
\hline & 262.62 & D_Af-77 & & 5.23 & D_Af-26 \\
\hline & 184.01 & D_Af-78-79-80 & & 9.91 & D_Af-28-29 \\
\hline & 184.01 & D_Af-81 & & 2.74 & D_Af-31-32 \\
\hline & 207.08 & D_Af-82 & & 6.06 & D_Af-33-34 \\
\hline & 207.08 & D_Af-83 & & 1.89 & D_Af-35 \\
\hline & 207.08 & D_Af-84-86 & & 5.42 & D_Af-36 \\
\hline & 207.08 & D_Af-85 & & 22.68 & D_Af-37--39 \\
\hline & 501.91 & D_Af-87 & & 5.15 & D_Af-40 \\
\hline & 100.97 & D_Af-87b & & 109.3 & D_Af-41 \\
\hline & 179.92 & D_Af-89 & & 376.5 & D_Af-42 \\
\hline & 648.55 & D_Af-90 & & 376.5 & D_Af-43 \\
\hline & & & & 376.5 & D_Af-45 \\
\hline
\end{tabular}

\subsection{Index of Basin Shape (Bs)}

Index of basin shape is calculated by using the following equation [21].

$$
B s=B l / B w
$$

In order to calculate this index in the region, we obtained the length of $B I$ and 
$B w$ using the map of sub-basins and channels and it values are divided to three categories of $B s>4,3<B s<4$ and $B s<3$ and has been shown in Table 1 and Figure 9 [8] [19] [20].

This index values are changed in the range from 0.87 to 5.32 and the average of basin shape index of Bashagard mountain is 2.13 for west basin, is 2.3 for the south basin and is 2.16 for east basin (Figure 9 and Table 3 ).

The distribution of Bs categories in the studied range in Figure 9 shows that category 1 in east has the maximum spread that convergence is caused by the tectonic collision activities resulted by strike-slip fault. Category 2 in the south and east mountain has a relatively lower tectonic activity. Category 3 has the lowest distribution and dale hill areas.

\subsection{Asymmetry Index of Channels in the Basin}

Asymmetry index of channels are used to evaluate the tectonic activity of tilting in the basin and to determine the direction of tilting [23] [24] [25]. This index is useful for large areas. It is also sensitive to tilting of vertical direction of channel [26]. Asymmetry index can be calculated by following formula [19]:

$$
A F=100(A r / A t)
$$

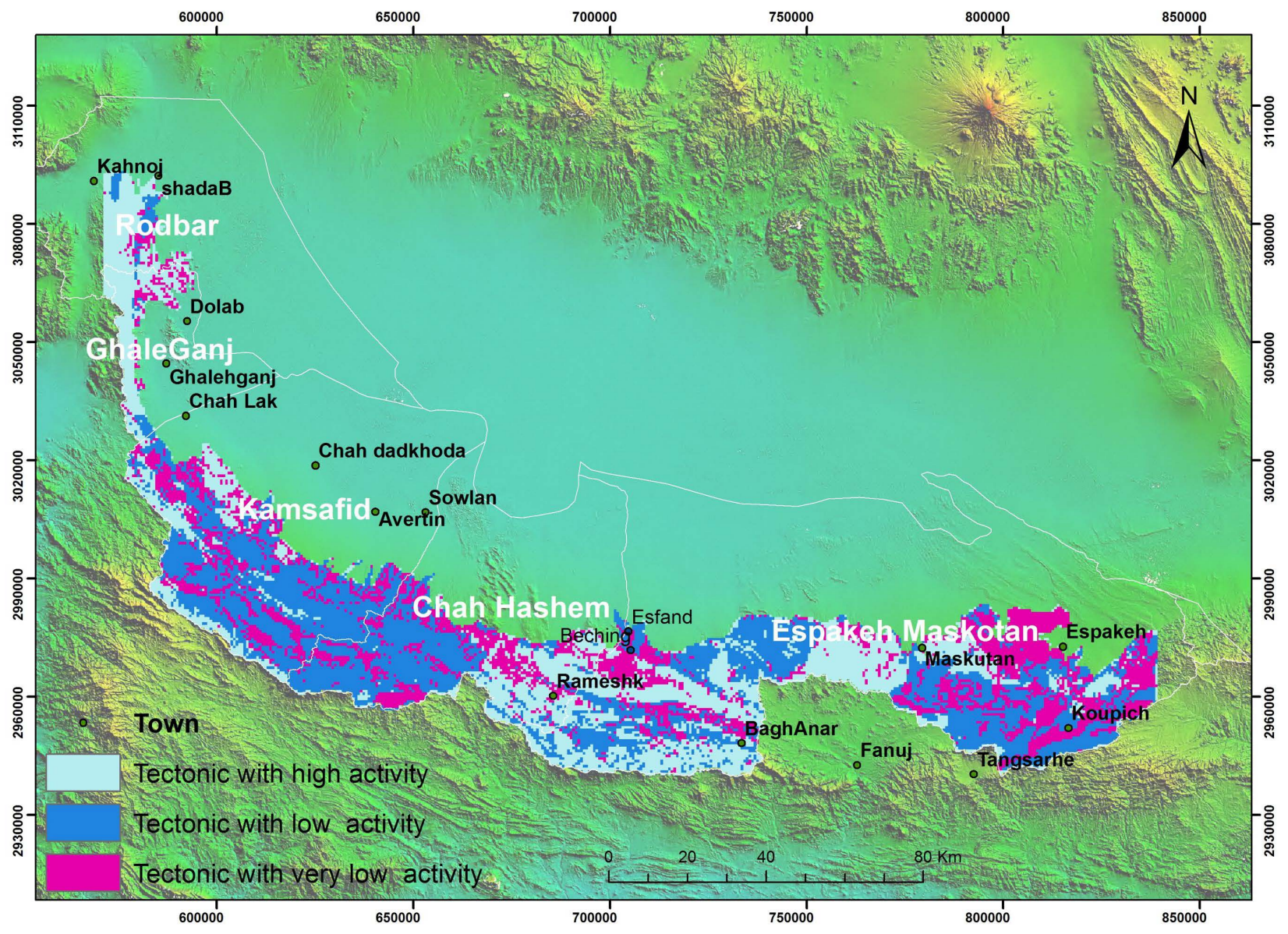

Figure 8. Distribution of numerical value index Mountain Front $(S m f)$ of basins Bashagard mountain. 


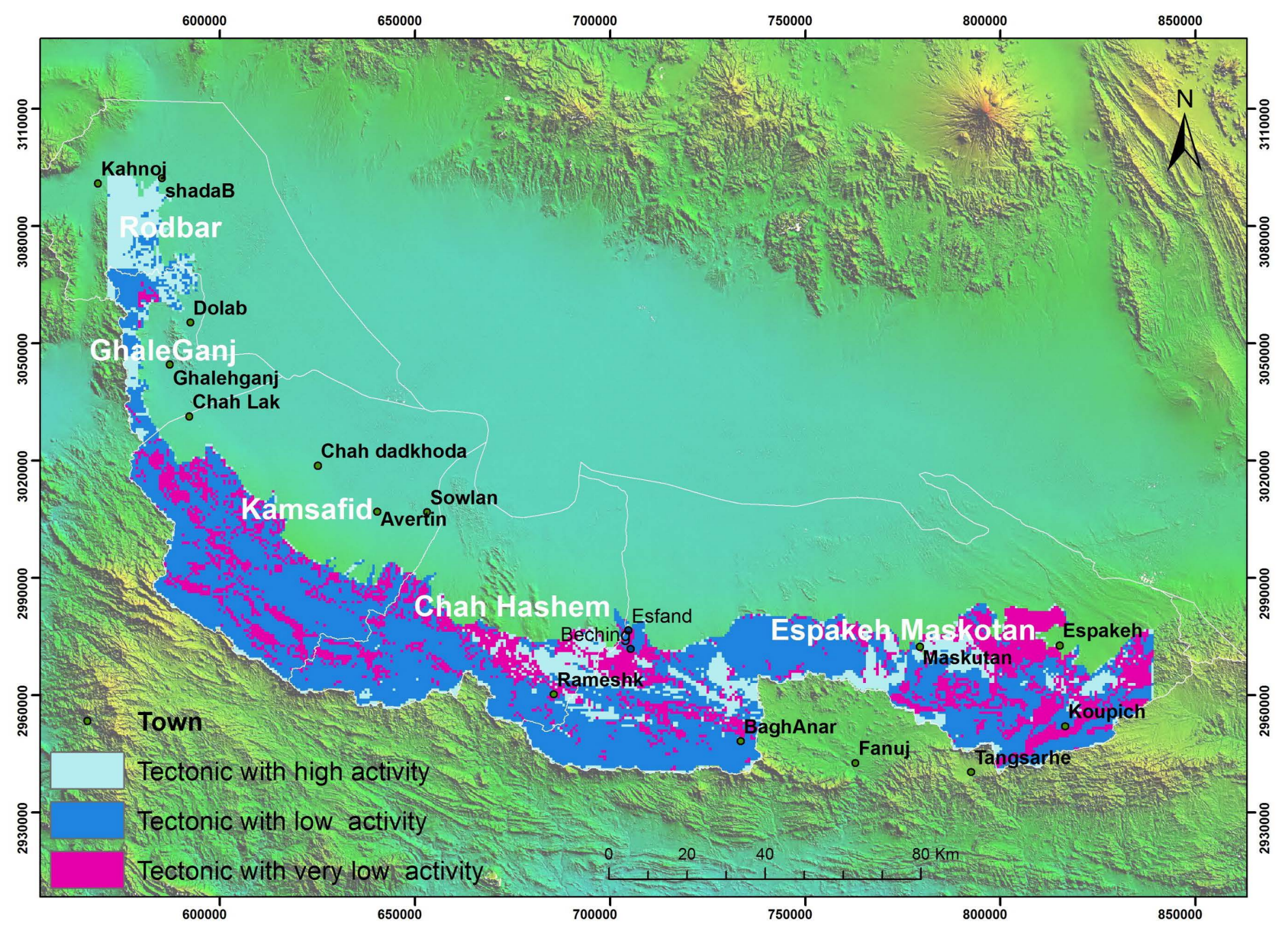

Figure 9. Distribution of numerical value index of basin shape $(B s)$ of basins Bashagard mountain.

$A F$ is asymmetry index of channels, $A r$ is the area of basin including subdrainage on the right side of beach of the main channel (square kilometer) and $A t$ is the area of basin including sub-drainage on the right and left sides of beach of the main channel (square kilometer).

$$
A F=50-\{100(A r / A t)\}
$$

We divided $A F$ values into four classes: $A F>5$ (symmetry basin), $A F=5-10$ (slightly asymmetry basin), $A F=5-10$ (moderate asymmetry basin) and $A F<$ 15 (highly asymmetry basin).

$A F$ values in the western part of the Bashagard mountain shows the asymmetry pattern on both sides of channels. According to these calculation, this index values are changed in the range from 10 to 90 and the average of channels asymmetry index of Bashagard mountain is 2.7 for west basin, is 2.5 for the south basin and is 1.7 for east basin (Figure 10 and Table 3).

\subsection{Vf Ratio}

Valley floor width to height ( $V f$ Ratio) is calculated as following [1]:

$$
V f=2 . V f w /[(E d i-E s c)+(E r d-E s c)]
$$


Table 3. Values of $B s, V f, A f, V f, \operatorname{Smf}, H i$ and $R A$ for Bashagard mountain (the south of Jazmurian subsidence.

\begin{tabular}{|c|c|c|c|c|c|c|c|c|}
\hline Name & $V f$ & $A f$ & $S L$ & $B S$ & $\mathrm{Hi}$ & $R H$ & $\operatorname{Smf}$ & $I R A T$ \\
\hline D_Af-1 & 1 & 1 & 2 & 2 & 2 & 2 & 3 & 2 \\
\hline D_Af-2 & 2 & 3 & 1 & 3 & 2 & 2 & 1 & 2 \\
\hline D_Af-3 & 2 & 3 & 1 & 2 & 2 & 1 & 1 & 2 \\
\hline D_Af-4 & 1 & 1 & 3 & 3 & 2 & 3 & 1 & 2 \\
\hline D_Af-4D & 1 & 1 & 2 & 2 & 2 & 1 & 1 & 1 \\
\hline D_Af-5 & 3 & 1 & 1 & 3 & 2 & 1 & 2 & 2 \\
\hline D_Af-8 & 2 & 2 & 2 & 2 & 2 & 1 & 2 & 2 \\
\hline D_Af-9 & 2 & 1 & 1 & 3 & 3 & 1 & 2 & 2 \\
\hline D_Af-11 & 2 & 1 & 1 & 3 & 3 & 1 & 2 & 2 \\
\hline D_Af-13 & 2 & 1 & 1 & 1 & 3 & 1 & 2 & 2 \\
\hline D_Af-141619 & 3 & 2 & 1 & 2 & 2 & 1 & 2 & 2 \\
\hline D_Af-21 & 2 & 2 & 2 & 2 & 2 & 2 & 2 & 2 \\
\hline D_Af-26 & 1 & 2 & 2 & 2 & 2 & 2 & 2 & 2 \\
\hline D_Af-28-29 & 3 & 3 & 3 & 3 & 2 & 1 & 2 & 2 \\
\hline D_Af-28-29 & 3 & 3 & 2 & 3 & 2 & 1 & 2 & 2 \\
\hline D_Af-31-32 & 3 & 3 & 2 & 2 & 2 & 2 & 2 & 2 \\
\hline D_Af-31-32 & 3 & 3 & 2 & 2 & 2 & 2 & 2 & 2 \\
\hline D_Af-35 & 3 & 1 & 3 & 3 & 2 & 3 & 2 & 2 \\
\hline D_Af-33-34 & 2 & 1 & 2 & 1 & 2 & 3 & 2 & 2 \\
\hline D_Af-36 & 3 & 1 & 3 & 2 & 2 & 3 & 2 & 2 \\
\hline D_Af-40 & 3 & 1 & 3 & 3 & 2 & 3 & 2 & 2 \\
\hline D_Af-41 & 3 & 1 & 3 & 3 & 2 & 2 & 2 & 2 \\
\hline D_Af-42 & 3 & 3 & 3 & 1 & 2 & 2 & 2 & 2 \\
\hline D_Af-43 & 3 & 3 & 2 & 1 & 2 & 2 & 2 & 2 \\
\hline D_Af-57 & 3 & 1 & 2 & 3 & 2 & 2 & 2 & 2 \\
\hline D_Af-58 & 3 & 3 & 2 & 3 & 2 & 2 & 2 & 2 \\
\hline D_Af-59 & 3 & 3 & 3 & 3 & 2 & 1 & 3 & 3 \\
\hline D_Af-60 & 3 & 3 & 2 & 3 & 2 & 1 & 3 & 2 \\
\hline D_Af-61 & 3 & 3 & 3 & 3 & 2 & 1 & 3 & 3 \\
\hline D_Af-62 & 2 & 2 & 2 & 3 & 2 & 1 & 3 & 2 \\
\hline D_Af-67 & 3 & 1 & 3 & 3 & 2 & 1 & 3 & 2 \\
\hline D_Af-68-69 & 1 & 2 & 2 & 3 & 2 & 1 & 1 & 2 \\
\hline D_Af-68-69 & 1 & 2 & 1 & 3 & 2 & 1 & 1 & 2 \\
\hline D_Af-70 & 3 & 2 & 3 & 1 & 2 & 1 & 2 & 2 \\
\hline D_Af-7475 & 1 & 1 & 1 & 1 & 2 & 1 & 1 & 1 \\
\hline D_Af-76 & 1 & 1 & 2 & 2 & 2 & 1 & 1 & 1 \\
\hline D_Af-77 & 1 & 2 & 1 & 2 & 2 & 2 & 1 & 2 \\
\hline D_Af-78-80 & 3 & 3 & 2 & 3 & 2 & 2 & 2 & 2 \\
\hline D_Af-82 & 3 & 1 & 2 & 3 & 2 & 2 & 2 & 2 \\
\hline D_Af-83 & 3 & 2 & 2 & 2 & 2 & 2 & 2 & 2 \\
\hline D_Af-84-86 & 3 & 3 & 1 & 2 & 2 & 1 & 2 & 2 \\
\hline D_Af-87 & 3 & 3 & 1 & 2 & 2 & 1 & 3 & 2 \\
\hline D_Af-87b & 3 & 3 & 2 & 1 & 2 & 2 & 3 & 2 \\
\hline D_Af-88 & 3 & 2 & 2 & 3 & 2 & 1 & 3 & 2 \\
\hline D_Af-90 & 3 & 1 & 2 & 3 & 2 & 1 & 3 & 2 \\
\hline
\end{tabular}




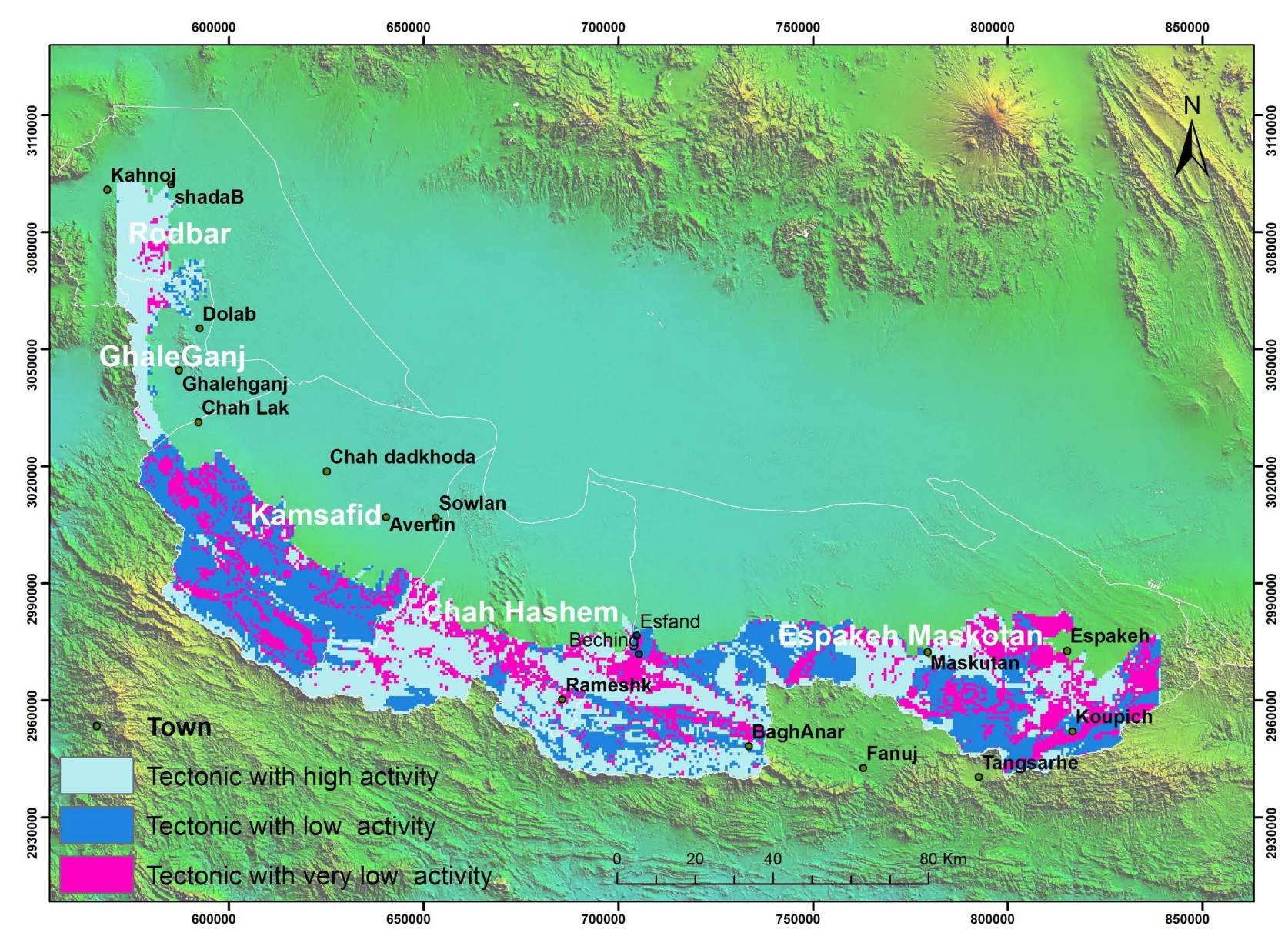

Figure 10. Distribution of numerical value asymmetry index of channels in the basin of basins Bashagard mountain.

where, $V f_{w}$ is valley floor width, Esc is valley floor height, Eid is the left side wall height and $E r d$ is the right side wall height.

Valley floor width to height ratio $V f$ was calculated in the range of this index values in 10 stations according to Table 3. According to these calculations, the mentioned index is changed in the range from 0.34 to 1.3 and its average is 0.68 . Therefore, the values of this index show the function of active tectonics and the presence of deep and almost V-shaped valleys in this range. Longitudinal profile of the river and above results are summarized in Table 3 were obtained.

As uplift is associated with depression, this index can indicate the degree of tectonic activity. So that the low value of $V f$ is associated with the higher value of depression and uplift. When there is a balance, depression and uplift are overlapped.

Valley floor width to height ratio $V f$ calculated in the range of this index values in 63 stations according to Table 3. According to these calculations, this index values are changed in the range from 0.18 to 42 and the average of this index is 1.42 for west basin, is 4.10 for the south basin and is 10.43 for east basin (Figure 11 and Table 3). Therefore, the values of this index show the function of active tectonics and the presence of deep and almost $\mathrm{V}$-shaped valleys in this range (Figure 11). The above results have been summarized in Table 3. 


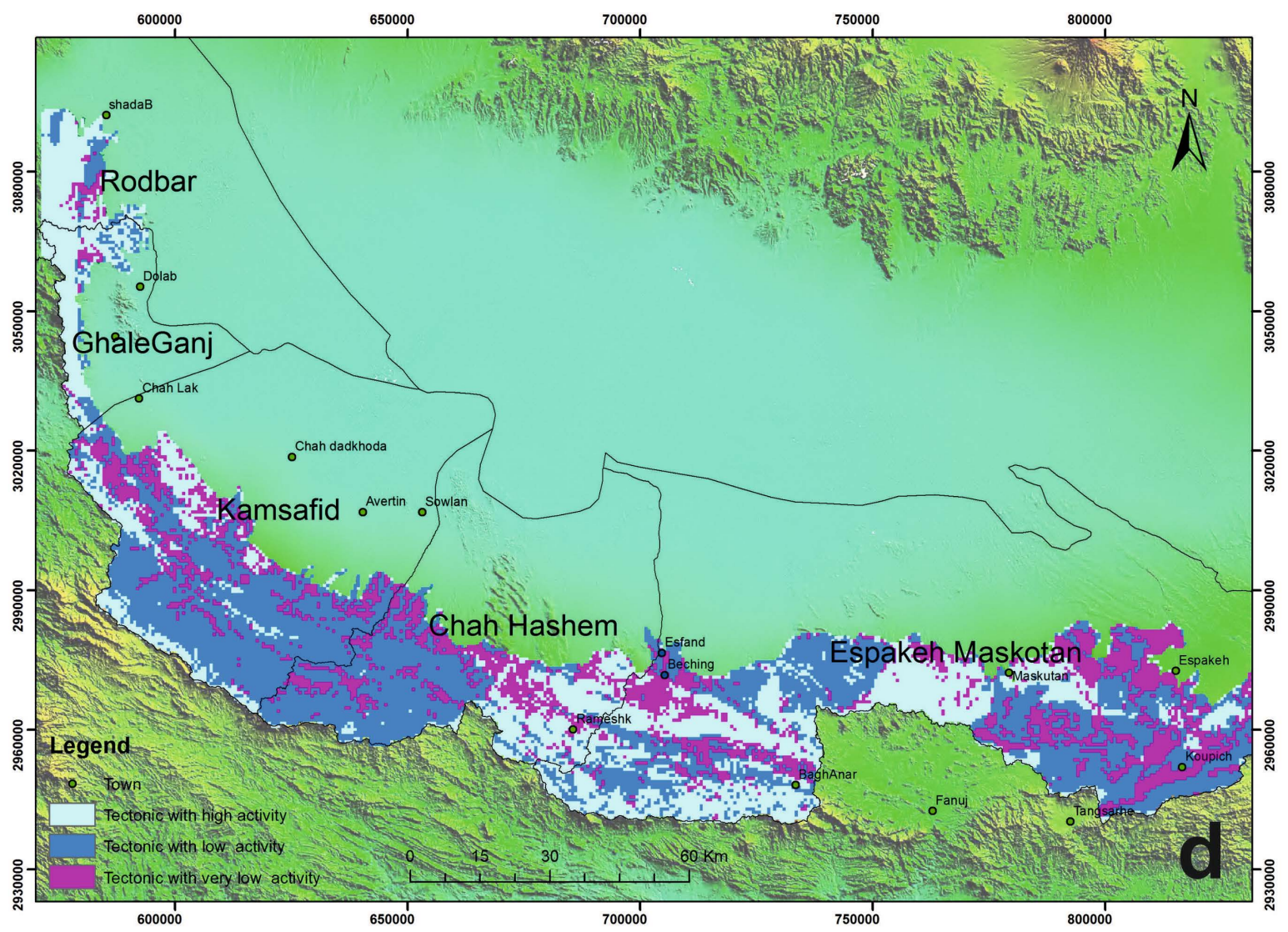

Figure 11. Distribution of numerical value $V f$ Ratio of basins Bashagard mountain.

\subsection{River Slope Index (SI)}

River slope index is a sensitive index to analyze the variability of range tectonic performance, rock resistance (Figure 6) and topography. This one can be used to assess drainage basin tectonic activity [19] [27] [28]. River slope or river gradient index is calculated by the following formula [18]:

$$
S l=(\Delta H / \Delta l) L
$$

$S L$ is river slope index, $\Delta H / \Delta l$ is local river gradient and $L$ is the length of the river from dividing line of channel to the center part whose gradient has been calculated.

Considering the river longitudinal profile, the $S I$ values were calculated and presented in Table 3. This index values are changed in the range from 150 to 1200 and the average of river slope index for Bashagard mountain is 319 for west river, is 264 for the south river and is 412 for east river (Table 3) that shows uplift function with low activity in the region (Figure 12, Figure 13 and Figure 14).

\subsection{Morphology Index $(R A)$}

$R A$ refers to the difference between the minimum and maximum height of Basin [20] [21]: 


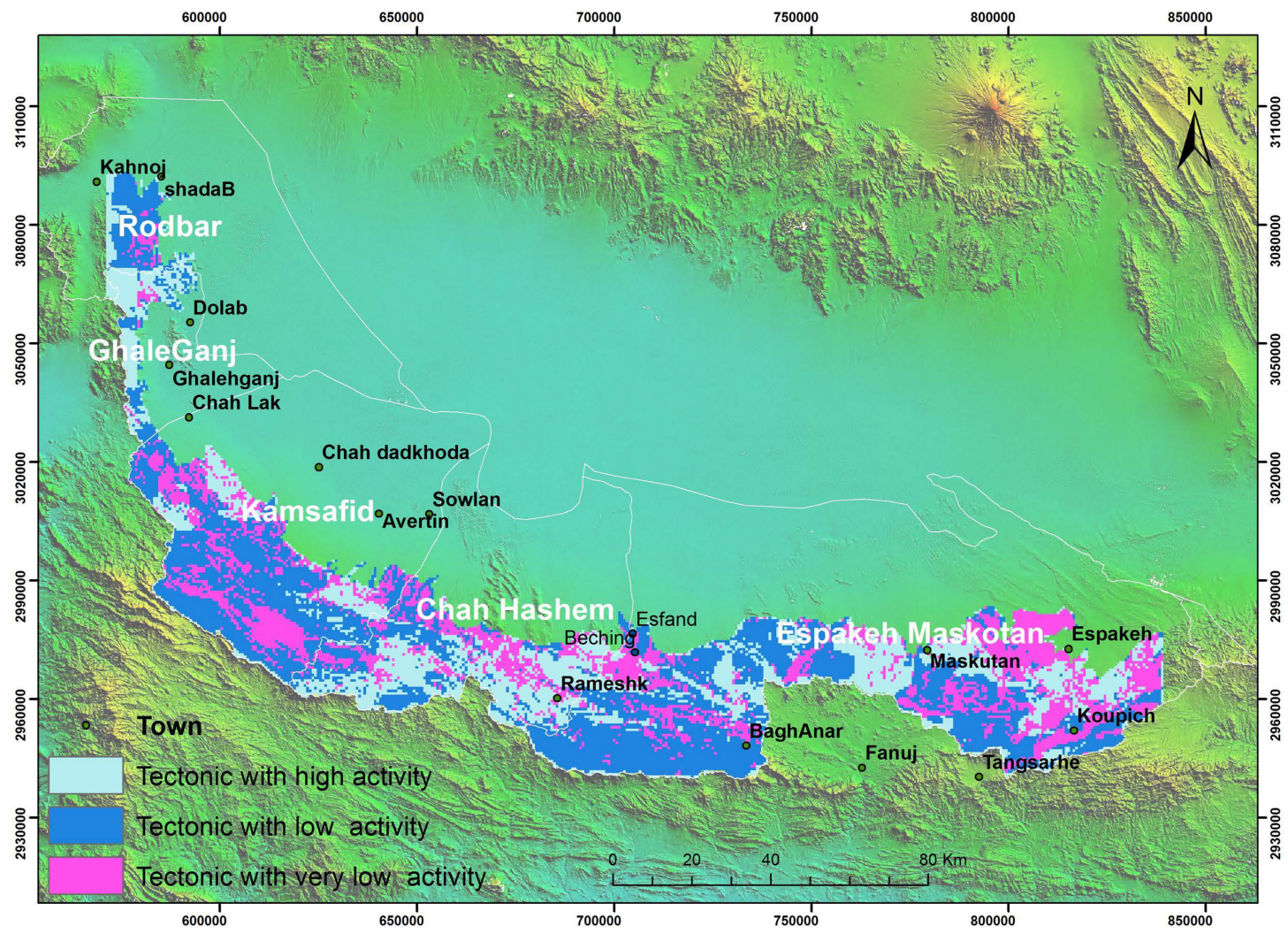

Figure 12. Distribution of numerical value River slope index $(S I)$ of basins Bashagard mountain.

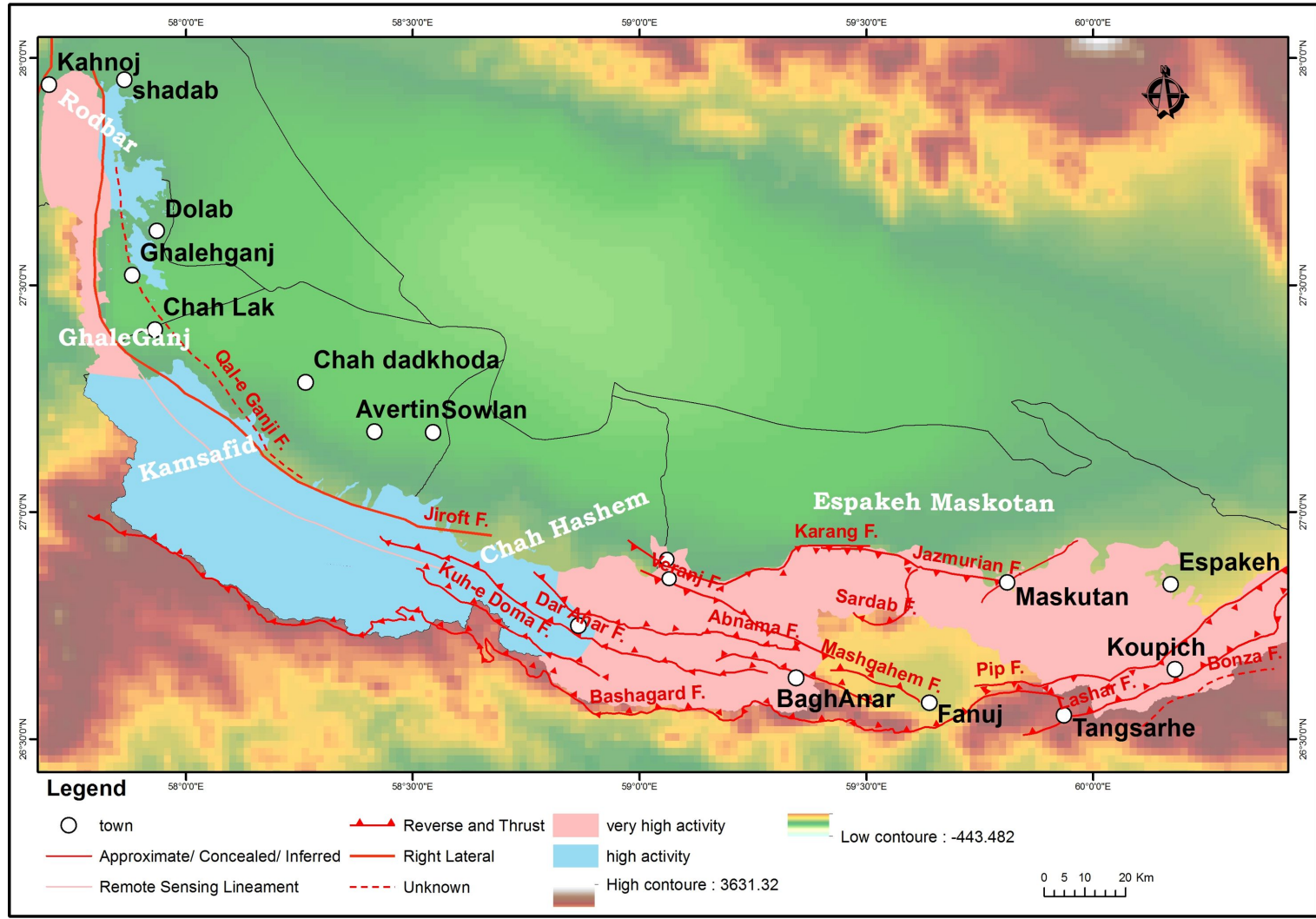

Figure 13. A view of the studied area tectonic activity on Dem map. 


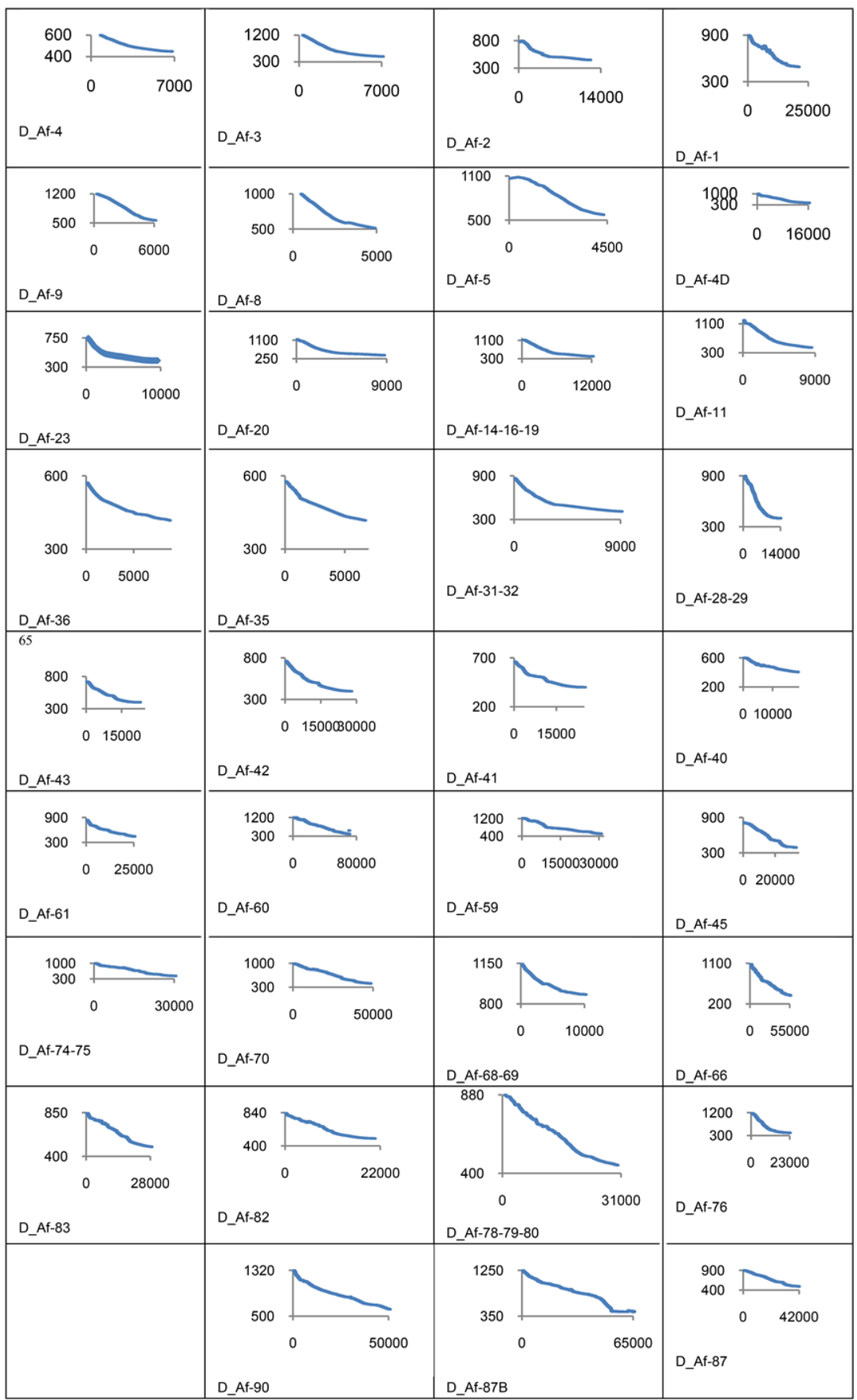

Figure 14. Diagram of river profiles of Bashagard mountains.

$$
R A=H \max / H \min
$$

where, $H \max$ and $H \min$ are the maximum and minimum height, respectively.

$R A$ expresses the depth of bluff and surface erosion, which can be described intensity of tectonic activity. Based on the digital morphometry classification [20], this index was divided into three classes: class $1(1000>)$, class 2 (500 $1000)$ and class $3(500<)$ (Table 3$). R A$ values are changed in the study area from 834 to 150 with an average of 273 . Several of basins for each class have been shown in Table 3. Class 2 has the largest basin area. 
Distribution of $R A$ classes in the study range has been shown in Figure 15. Class 1 has the maximum spread that is in accordance with convergence caused by the tectonic activity. Category 2 further inside the mountain is covered with tectonic activity that deposits are relatively less. Category 3 has the lowest distribution and areas are hilly (Table 3) (Figure 15).

\subsection{Index of Catchment Area (Hi)}

Generally, $H i$ is as independent index for a specific catchment basin. $H i$ explains distribution of height of area of constructs, in particular drainage basin [29]. Tectonic uplift curve index show the catchment area volume that has not been eroding. $H i$ is as follows:

$$
H i=H \text { mean }-H \min / H \max -H \min
$$

where, Hmean is the average of basin height.

High values of $\mathrm{Hi}$ refers to the younger constructs, which have likely been developed by tectonic activity, it generally is in accordance with the state that the majority of mountain have not been eroding. Moreover, high values of $\mathrm{Hi}$ are as a result of recent bluff of young area morphometry created by sediments. Low values are related to the older land, which has been manly eroding and has the lowest tectonic activity [9].

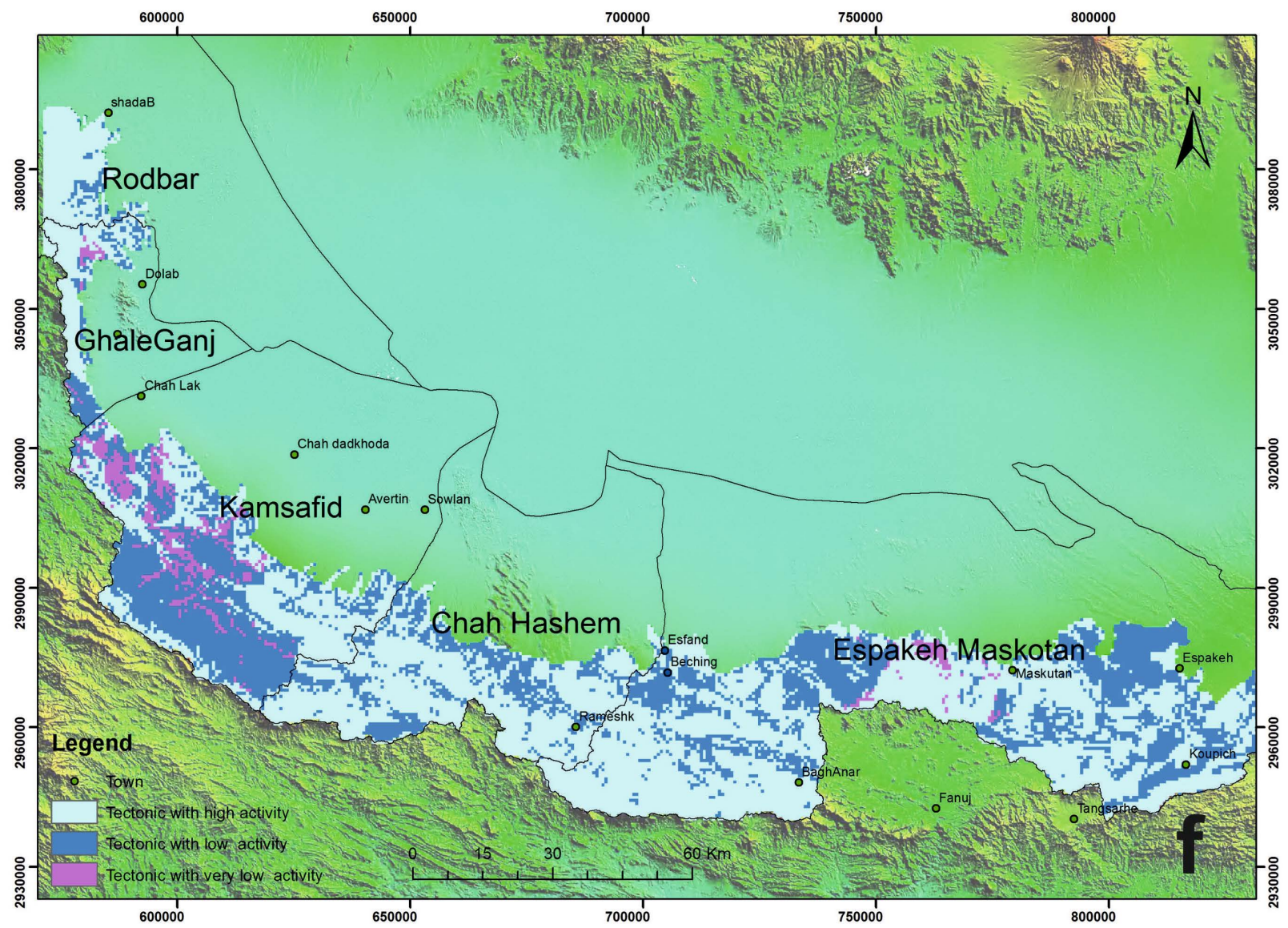

Figure 15. Distribution of numerical value morphology index $(R A)$ of basins Bashagard mountain. 
This index was calculated for all basins in the studied area that the lowest value was obtained 0.4 and the maximum value was obtained 0.5 . According to the curve, values are divided into three categories: category $1(0.5<)$, category $2(0.4$ $0.5)$ and category $3(<0.4)$ [9] (Table 3 and Figure 16).

\subsection{IRAT Calculation}

Some previous studies compared two or more indices with obtaining a few of information about tectonic activity of mountains [8] [29]. The use of the seven above-mentioned morphometric features and IRAT provide tectonic active regions in the studied area. We collected the division content of the results of previous studies [29] [30] [31]. Content of classification and morphometry of the seven indices in 45 stations in Bashagard mountain has been shown in Table 2. With more accurate results, two indices were in category 3 , eight indices were in classes 1 and 33 indices were in category 2 and each category is assigned to one value. This division is summation and averages of IRAT information within the studied area (Figure 17).

$$
I R A T=(R A+H i+S l+B s+A f+S m f+V f) / 7
$$

These calculations have been used in different tectonic regions [8] [9] [21] [31].

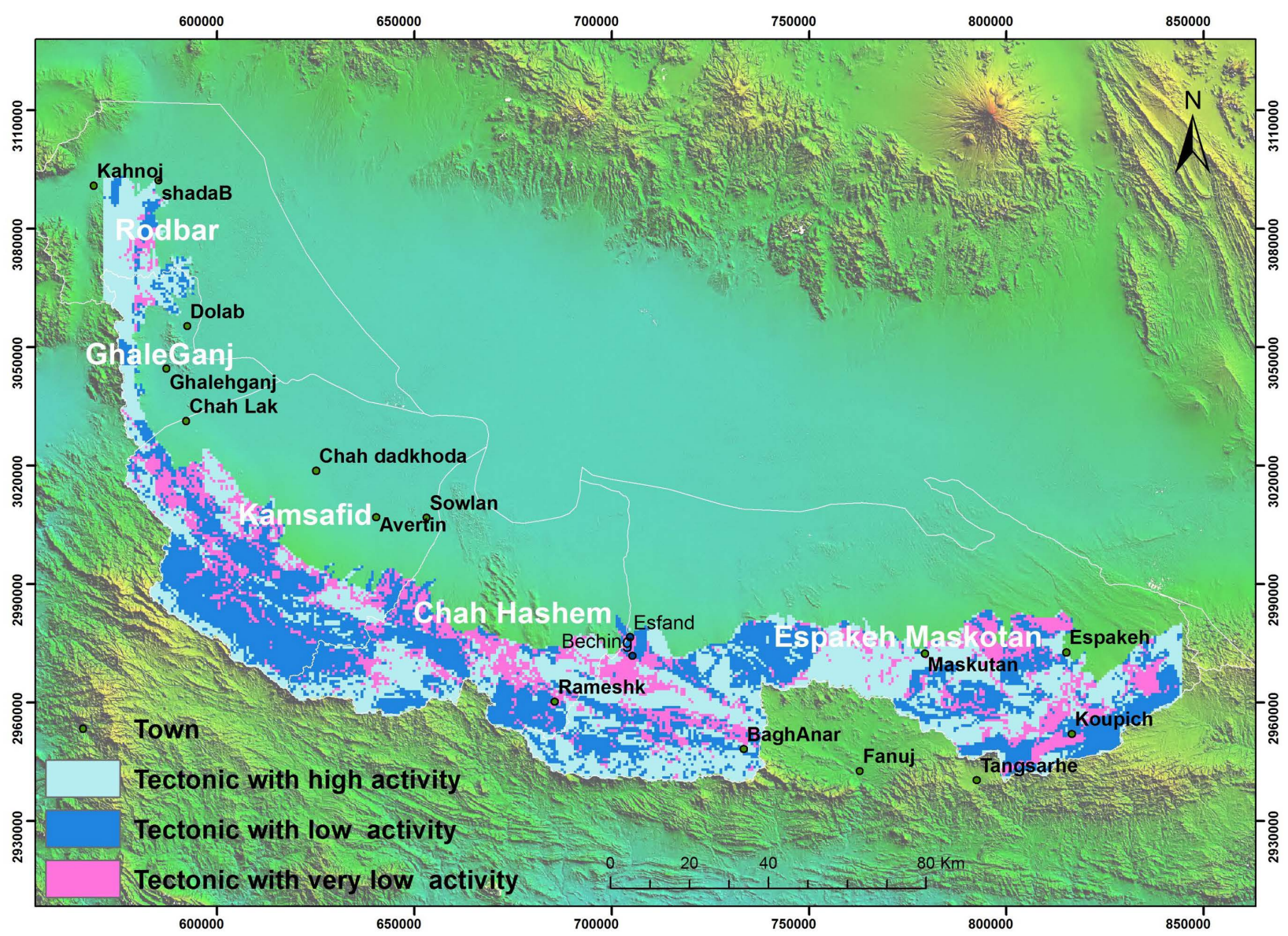

Figure 16. Distribution of numerical value morphology index $(R A)$ of basins Bashagard mountain. 


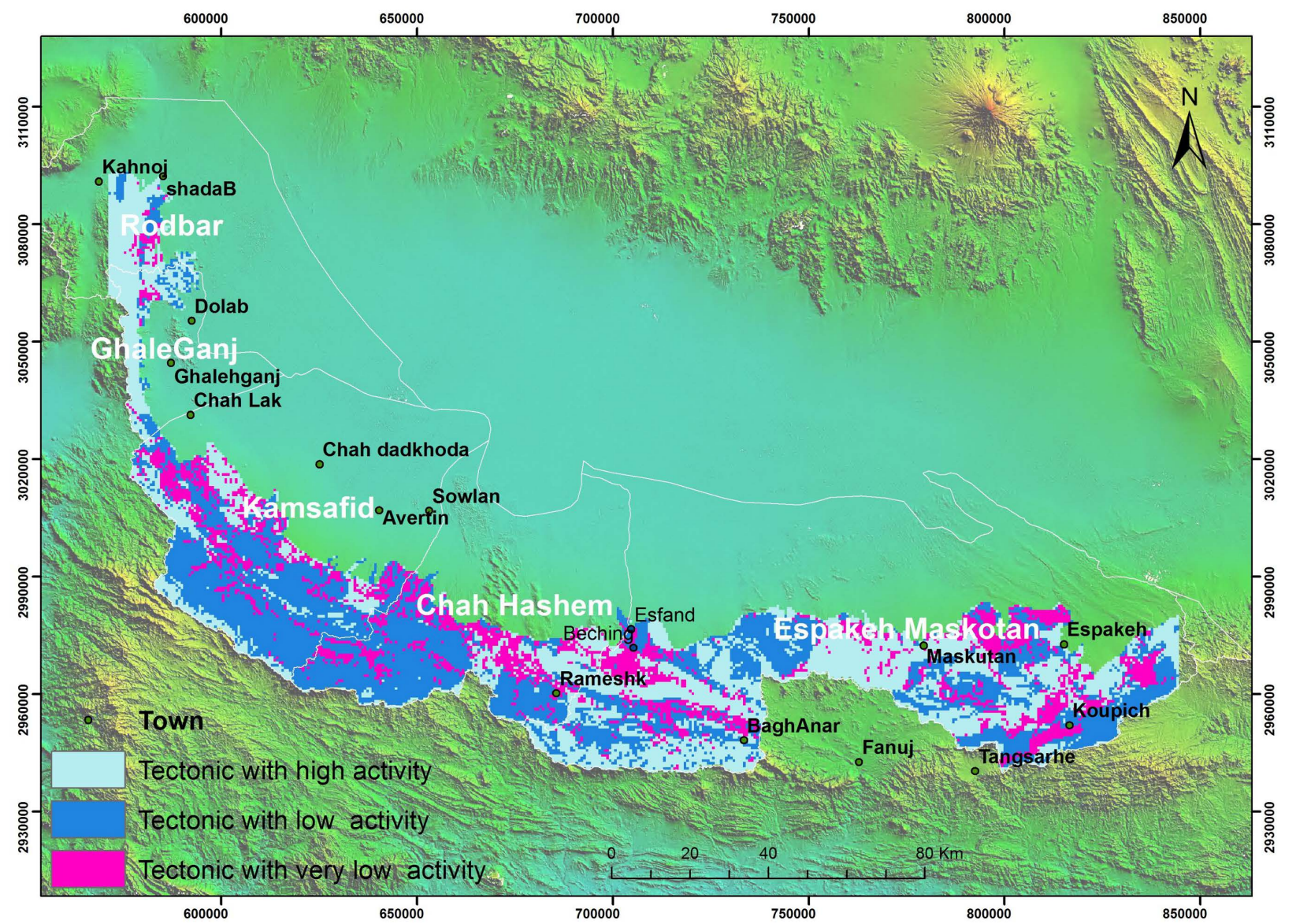

Figure 17. Distribution of numerical value IRAT calculation of basins Bashagard mountain.

\section{Analysis of the Longitudinal Profile of the River}

Longitudinal profile of the river (LRP) is an analytical in the tectonic research field. longitudinal profile of the river is a very sensitive lineament of entire basin to earth's crust tectonic deformation [32] [33] [34] [35].

Longitudinal profile of the river is defined as the result of the balance between erosion and uplift rate [2] [19] that depends on morphology profile, uplift rate and monthly precipitation (as factor for denudation rate).

Concave profiles are as a result of long-term balance between the uplift and erosion rate. Concave-convex profiles that appear by erosion process refer to the long-term overcome to erosion processes. Convex profiles are of the characteristics of the areas where uplift (active tectonics) is dominant. Valuable information can be also obtained from linear sections of mountains [2].

One of the advantages of mountain linear sections is that their length is similar to the longitudinal section of channels. These sections can create a view of the surface structure of the land for each basin that helps to compare the relative erosion of blocks in different basins.

With the discovery of the role of stages of development constructs in river channel adjustment, longitudinal profile of the river was provided for all main channels in Bashagard mountain. 

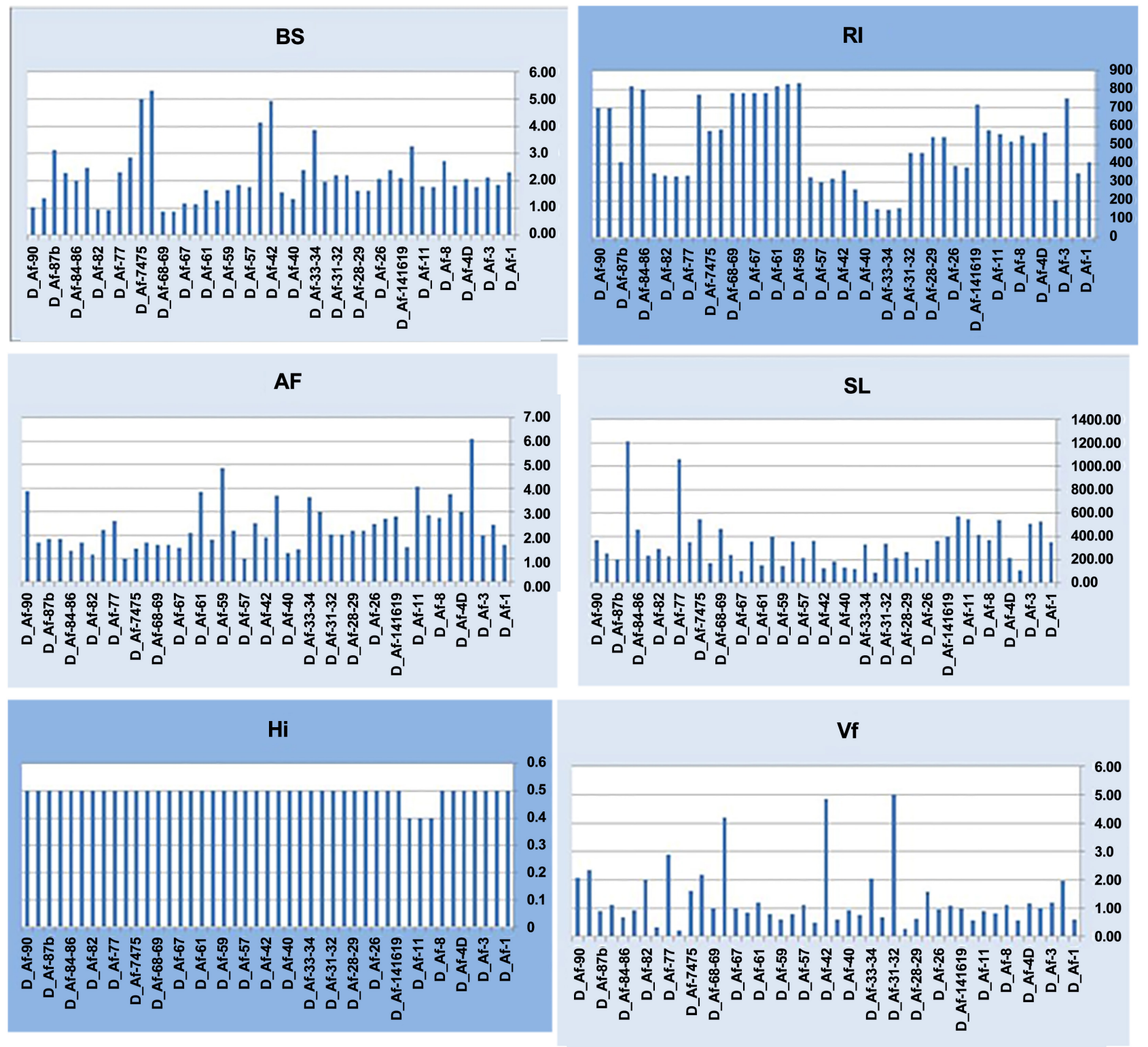

Figure 18. Diagram of amount of $R h, H i, S f, S l, B s, A f, S m f$ for Bashagard Mountain

All main channels have been updated using the topographic map $(1: 25,000)$ and Google Earth images (2015) with open layers in GIS and editing tools for vector lines with fewer errors and ASTER elevation data (Figure 7, Figure 14).

\section{Results and Discussion}

Geomorphic indices can provide useful and reliable method to study the tectonic activity rate. When several morphotectonic indicators used together in a particular area to investigate and analyze tectonic activity, the results are more logical, reasonable and significant comparing to using only one index. Therefore, in order to achieve optimal results and to assess the tectonic state of the mountain, seven different geomorphic indices ( $S m f, V f, A f, S l, B S, H i, R A$ ) were used. The results of the analysis of these indices in the studied area through analysis of to- 
pography, the shape of the basin, the drainage shape, the states of basin network, valley morphology and basins symmetry that show that the overall appearance of the area is largely as a result of area tectonic activities, particularly function of faults of Jiroft, kale Ganj, Karang, Varang, Jazmurian and Bashagard bluff that have activity in the desired area.

The achievements of morphometric index show tectonic activity of Bashagard mountain is determined by the surface geological characteristics includingmorphology of alluvial fan, triangular surface of mountain front and diversion of channels (Figure 3 and Figure 4). Moreover, it has controlled the tectonic of geometric and sedimentary patterns of alluvial fans.

The front of west Bashagard mountain has been specified with low values of $S m f$ and $V f$ that the values of $S m f$ and $V f$ are increasing towards the south and east. The presence of quaternary alluvial fans along the mountain front and drainage network model is a response for the low values of $S m f$ and $V f$. The presence of several along strike-slip and reverse faults in the north and west of mountain front indicates the active tectonic in the region (Figure 13).

Asymmetry index for Bashagard mountain basins was calculated to detect large-scale activities and tilting. $F$ values in the western part of the Bashagard mountain show a pattern of asymmetry on both sides of the river that are resulted by tectonic activity. In this section, there is Jiroft fault with strike-slip motion. In the south and east of Bashagard mountain, there are several symmetrical basin patterns (Figure 1 and Figure 2).

Quaternary uplift rate is rare in Bashagard mountain and there is no enough information about this, considering the active convergence rate between the Arabic plate and the Makran coast, which is measured in Muscat of Oman and coast Chabahar of Iran, it is $1.9 \mathrm{~cm} /$ year, and today the convergence rate between the Makran coast (Chabahar GPS) and Eurasian shield is $8 \mathrm{~cm} /$ year [13]. Therefore, Bashagard mountain tectonic uplift is quaternary.

Based on the figure, the west basins are tectonically active area and long and the minimum belongs to the south and east basins, which are circular type and tectonically inactive. Morphometric indices show the tectonic activity of Bashagard mountain. These areas have long tectonically active basin (Figure 13).

Morphometric index of tectonic including the uplift savior, longitudinal profile of channels and drainage patterns indicate southern-northern and easternwestern instability. These changes are caused by differences in altitude of 2000 meters in mountain front and 400 meters in Jarmvryan subsidence. Mountain channels have the erosion ability. Southern and southeast channels are longer and wider and channels of west mountain are nearly deeper and shorter and with movement. This difference in altitude and type of channels can be dependent on the difference of tectonic activity.

Expansion of a tectonic model for the tectonic evolution of Bashagard mountain is not simple because it seems stretching and compression activities in this area has historical activity. Quaternary stress with north compression and northeast compression with axis stretching have been specified. Therefore, tensile 
and compression structures were formed at this time. All area is as a result of the north and northeast compression in the Pliocene when the strike-slip and normal faults with north-south, northwest-southeast direction and reverse faults with east-west and northwest-southeast direction continuously with extensional tectonic with northwest-southeast direction have occurred.

This scenario is the overall result of our studies with tectonic activity in the indenture mountain along mountain front, which includes strike-slip fault with a nearly east slope and a reverse fault with depression north block of the mountain (Jazmurian subsidence) and is pretty consistent with mountain uplift.

This is a visual model of the mountain front as a result of tectonic activity that its situation is not almost in accordance with morphometric calculations, because difference between the height and the shape of drainage basins in west, southwest, south and southeast is probably due to the tectonic situation of basins.

Basins of west and southwest of Bashagard mountain have been formed in east of Jazmurian subsidence with a strike-slip fault system in direction of northsouth and northwest-southeast and quaternary subsidence. South and southeast basins of the Bashagard mountain are located at top wall of compressional fault system.

\section{Conclusions}

Calculation of morphometry index using GIS is suitable for assessing tectonic activity of large areas. This method was used for the Bashagard mountain area in north Makran with identifying the morphometric shape and evaluating the tectonic activity due to the lack of appropriate works on tectonic activity and the lack of seismic report in the studied area.

We divide tectonic activity into three categories using seven morphometric indices of river gradient index (SL), basin asymmetry $(A f)$, hypsometric curve $(H i)$, valley height ratio ( $V f)$, drainage basin shape (Bs), sinuosity mountain front ( $S m f)$, $R f$ and the total of seven above mentioned indices (IRAT).

The values of Hi, Bs and SL are high along the faults. Values of basin asymmetry $(A f)$ is related to tectonic tilting. The values of sinuosity mountain front $(S m f)$ have tectonic activity. The values of $V f$ show several narrow and steep valley. The high rate of bluff shows continues tectonic uplift.

In both studied area, IRAT values have almost category 2 that show the high tectonic activity. The IRAT values of category 1 have the maximum tectonic activity that mainly occurs along Jiroft and Jazmurian faults. Category 2 of IRAT is related to high tectonic activity that occurs along the faults of Jiroft and Kaleh Ganj. These categories are also in accordance with triangular surfaces of tectonic bluffs, deformation of alluvial fans and deep and narrow valleys (Figure 13).

All morphometry indices used in this article for the Bashagard mountain tectonic activity model are appropriate for activity of west and south front in response to strike-slip and reverse faults, respectively. This tectonic model describes the topography difference between the basins. Basins of west and south- 
west of Bashagard mountain have been formed in east of Jazmurian subsidence with a strike-slip fault system in direction of north-south and northwest-southeast and quaternary subsidence. South and southeast basins of the Bashagard mountain are located at top wall of compressional fault system.

The above results confirm advantages of morphometry analysis to assess the regional tectonic. They also offer a detailed investigation for the future of tectonic in the studied area based on accurate geological features, quaternary archeology and large tectonic features.

\section{References}

[1] Bull, W.B. (2009) Geomorphic Responses to Climatic Change. Blackburn Press, Caldwell, 326 p.

[2] Burbank, D.W. and Anderson, R.S. (2012) Tectonic Geomorphology. Blackwell Science, Malden.

[3] Pérez-Peña, J.V., Azor, A., Azañón, J.M. and Keller, E.A. (2010) Active Tectonics in the Sierra Nevada (Betic Cordillera, SE Spain): Insights from Geomorphic Indexes and Drainage Pattern Analysis. Geomorphology, 119, 74-87. https://doi.org/10.1016/j.geomorph.2010.02.020

[4] Azañón, J. M., Pérez-Peña, J.V., Giaconia, F., Booth-Rea, G., Martínez-Martínez, J.M. and Rodríguez-Peces, M. J. (2012) Active Tectonics in the Central and Eastern Betic Cordillera through Morphotectonic Analysis: The Case of Sierra Nevada and Sierra Alhamilla. Journal of Iberian Geology, 38, 225-238

[5] Gao, M.X., Zeilinger, G., Xu, X.W., Wang, Q.L. and Hao, M. (2013) DEM and GIS Analysis of Geomorphic Indices for Evaluating Recent Uplift of the Northeastern Margin of the Tibetan Plateau, China. Geomorphology, 190, 61-72. https://doi.org/10.1016/j.geomorph.2013.02.008

[6] Melosh, B.I. and Keller, E.A. (2013) Effects of Active Folding and Reverse Faulting on Stream Channel Evolution, Santa Barbara Fold Belt, California. Geomorphology, 186, 119-135. https://doi.org/10.1016/j.geomorph.2012.12.027

[7] Pérez-Peña, J.V., Azañón, J.M. and Azor, A.C. (2009b) An ArcGIS Extension to Calculate Hypsometric Curves and Their Statistical Moments. Applications to Drainage Basin Analysis in SE Spain. Computers \& Geosciences, 35, 1214-1223. https://doi.org/10.1016/j.cageo.2008.06.006

[8] El, H.R., Irigaray, C., Fernandez, T., Chacon, J. and Keller, E.A. (2008) Assessment of Relative Active Tectonics, Southwest Border of the Sierra Nevada (Southern Spain). Geomorphology, 96, 150-173. https://doi.org/10.1016/j.geomorph.2007.08.004

[9] Mahmood, S.A. and Gloaguen, R. (2012) Appraisal of Active Tectonics in Hindu Kush: Insights from DEM Derived Geomorphic Indices and Drainage Analysis. Geoscience Frontiers, 3, 407-428. https://doi.org/10.1016/j.gsf.2011.12.002

[10] Alipoor, R., Poorkermani, M., Zare, M. and El, H.R. (2011) Active Tectonic Assessment around Rudbar Lorestan Dam Site, High Zagros Belt (SW of Iran). Geomorphology, 128, 1-14. https://doi.org/10.1016/j.geomorph.2010.10.014

[11] Smith L.C., McNeil, l., Wang, K., He, J., Timothy, J. and Henstock, T.J. (2013) Thermal Structure and Megathrust Seismogenic Potential of the Makran Subduction Zone.

[12] Vernant, P.h., Nilforoushan, F., Hatzfeld, D., Abbassi, M.R., Vigny, C., Masson, F., Nankali, H., Martinod, J., Ashtiani, A., Bayer, R., Tavakoli, F. and Chery, J. (2004) 
Present-Day Crustal Deformation and Plate Kinematics in the Middle East Constrained by GPS Measurements in Iran and Northern Oman. Geophysical Journal International, 157, 381-398. https://doi.org/10.1111/j.1365-246X.2004.02222.x

[13] Walpersdorf, A., et al. (2014) Present-Day Kinematics and Fault Slip Rates in Eastern Iran, Derived from 11 Years of GPS Data. Journal of Geophysical Research: Solid Earth, 119, 1359-1383. https://doi.org/10.1002/2013JB010620

[14] Burg, J.P., Bernoulli, D., Dolati, A., Muller, C., Smit, J. and Spezzaferri, S. (2012) Stratigraphy and Structure of the Iranian Makran.

[15] Burg, D., Bernoulli, D.A., Muller, C., Smith, J. and Spezzaferri, S. (2013) Stratigraphy and Structure of the Iranian Makran. Search and Discovery.

[16] Dolati, A. (2010) Stratigraphy, Structure Geology and Low-Temperature Thermochronology across the Makran Accretionary Wedge in Iran. PhD Thesis, ETH, Zurich.

[17] Madavi, E.A. (1987) Jazmurian Range of Geological Maps, Sheet Fenouj Number K14 Scale of 1: 250,000 Geological and Mineral Exploration Iran.

[18] Marinos, P. and Hock, E. (2001) Estimating the Geotechnical Properties of Heterogeneous Rock Masses Such as Flysck. Bulletin of Engineering Geology and the Environment, 60, 85-92. https://doi.org/10.1007/s100640000090

[19] Cheng, W.M., Zhou, C.H., Li, B.Y. and Zhang, B.P. (2011) Structure and Contents of Layered Classification System of Digital Geomorphology for China. Journal of Geographical Sciences, 21, 771-790. https://doi.org/10.1007/s11442-011-0879-9

[20] Cheng, W.M., Wang, N., Zhao, M. and Zhao, S. (2016) Relative Tectonics and Debris Flow Hazards in the Beijing Mountain Area from DEM-Derived Geomorphic Indices and Drainage Analysis. Geomorphology, 257, 134-142.

https://doi.org/10.1016/j.geomorph.2016.01.003

[21] Keller, E.A. and Pinter, N. (2002a) Active Tectonics: Earthquakes, Uplift and Landscape. 2nd Edition. Prentice Hall, Upper Saddle River, 362 p.

[22] Keller, E.A. and Pinter, N. (2002b) Active Tectonics: Earthquakes, Uplift and Landscape. 2nd Edition. Prentice Hall, Upper Saddle River, 362 p.

[23] Kale, V.S., Sengupta, S., Achyuthan, H. and Jaiswal, M.K. (2014) Tectonic Controls upon Kaveri River Drainage, Cratonic Peninsular India: Inferences from Longitudinal Profiles, Morphotectonic Indices, Hanging Valleys and Fluvial Records. Geomorphology, 227, 153-165. https://doi.org/10.1016/j.geomorph.2013.07.027

[24] Sarma, J.N., Acharjee, S. and Murgante, G. (2013) Morphotectonic Study of the Brahmaputra Basin Using Geoinformatics. Geophysical Research Abstracts, 15, 14001.

[25] Siddiqui, S. (2014) Appraisal of Active Deformation Using DEM-Based Morphometric Indices Analysis in Emilia-Romagna Apennines, Northern Italy. Geodynamics Research International Bulletin, 1, 34-42.

[26] Sboras, S., Ganas, A. and Pavlides, S. (2010) Morphotectonic Analysis of the Neotectonic and Active Faults of Beotia (Central Greece), Using GIS Techniques. Bulletin of the Geological Society of Greece, 36, 1607-1618.

[27] Dar, R.A., Romshoo, S.A., Chandra, R. and Ahmad, I. (2014) Tectono-Geomorphic Study of the Karewa Basin of Kashmir Valley. Journal of Asian Earth Sciences, 92, 143-156. https://doi.org/10.1016/j.jseaes.2014.06.018

[28] Zhang W., Hayakawa Y.S. and Oguchi, T. (2011) DEM and GIS Based Morphometric and Topographic-Prole Analyses of Danxia Landforms. Geomorphometry, 121-124. 
[29] Silva, P.G., Goy, J.L. and Zazo, C. (2003) Fault Generated Mountain Fronts in Southeast Spain: Geomorphologic Assessment of Tectonic and Earthquake Activity. Geomorphology, 250, 203-226. https://doi.org/10.1016/S0169-555X(02)00215-5

[30] Strahler, A.N. (1952) Hypsometric (Area-Altitude) Analysis of Erosional Topography. Geological Society of America Bulletin, 63, 1117-1142. https://doi.org/10.1130/0016-7606(1952)63[1117:HAAOET]2.0.CO;2

[31] Dehbozorgi, M., Pourkermani, M., Arian, M., Matkan, A.A., Motamedi, H. and Hosseiniasl, A. (2010) Quantitative Analysis of Relative Tectonic Activity in the Sarvestan Area, Central Zagros, Iran. Geomorphology, 121, 329-341. https://doi.org/10.1016/j.geomorph.2010.05.002

[32] Lahiri, S.K. and Sinha, R. (2012) Tectonic Controls on the Morphodynamics of the Brahmaputra River System in the Upper Assam Valley, India. Geomorphology, 169-170, 74-85. https://doi.org/10.1016/j.geomorph.2012.04.012

[33] Viveen, W., van, B.R.T., Schoorl, J.M., Veldkamp, A., Temme, A.J.A.M. and VidalRomani, J.R. (2012) Assessment of Recent Tectonic Activity on the NW Iberian Atlantic Margin by Means of Geomorphic Indices and Field Studies of the Lower Miño River Terraces. Tectonophysics, 544-545, 13-30. https://doi.org/10.1016/j.tecto.2012.03.029

[34] Fekete, K. and Vojtko, R. (2013) Neotectonic Activity of the Pravno Fault in the Area of the Ziar Mts. Acta Geologica Slovaca, 5, 117-127.

[35] Goren, L., Fox, M. and Willett, S.D. (2014) Tectonics from Fluvial Topography Using Formal Linear Inversion: Theory and Applications to the Inyo Mountains, California. Journal of Geophysical Research: Earth Surface, 119, 1-11.

Submit or recommend next manuscript to SCIRP and we will provide best service for you:

Accepting pre-submission inquiries through Email, Facebook, LinkedIn, Twitter, etc. A wide selection of journals (inclusive of 9 subjects, more than 200 journals) Providing 24-hour high-quality service User-friendly online submission system Fair and swift peer-review system Efficient typesetting and proofreading procedure Display of the result of downloads and visits, as well as the number of cited articles Maximum dissemination of your research work

Submit your manuscript at: http://papersubmission.scirp.org/

Or contact ojg@scirp.org 